\title{
Chemical deposits in evaporite caves: an overview
}

\author{
Paolo Forti \\ Italian Institute of Speleology, Via Zamboni 67, 40126 Bologna, Italy
}

\begin{abstract}
Chemical deposits inside evaporite (gypsum, anhydrite and halite) caves are far less common than those developed within limestone or volcanic cavities. Moreover they exhibit a lower scarce mineralogical variability due to several reasons, the most important of which are: 1) calcium sulfate and sodium chloride are by far less reactive than calcium carbonate; 2 ) evaporite outcrops normally have a low mineralogical variability within the cave recharge areas. Therefore these karst environments were less investigated from this point of view in the past: no general paper exists on speleothems developing in halite and anhydrite caves until present, while the last printed one on gypsum (and anhydrite) karst appeared around 20 years ago. Several mineralogical studies were carried out in the last decades in caves from different evaporite areas proving that some of them host peculiar minerogenetic mechanisms, which are, at the moment, exclusive for these areas, and sometimes also brought to light to rare or even new cave minerals. In the present paper, together with an overview on all the actually known minerogenetic mechanisms active within the evaporite caves, the related chemical deposits and speleothems are shortly described. Far from being exhaustive, the recent mineralogical research on evaporite caves puts in evidence their unexpected richness in peculiar hosted speleothems and rare cave deposits. Seven out of the fifty known evaporite cave minerals, and around 10 speleothem types/subtypes are exclusive to these environments. Taking into account that only a few evaporite areas have been, so far, studied, it is highly probable that in the near future many more new cave deposits will be discovered, thus increasing the mineralogical interest of these unique caves.
\end{abstract}

Keywords: minerogenetic mechanisms, speleothems, evaporite caves, gypsum, halite

Received 26 September 2016; Revised 21 January 2017; Accepted 23 January 2017

Citation: $\quad$ Forti P., 2017. Chemical deposits in evaporite caves: an overview. International Journal of Speleology, 46 (2), 109-135. Tampa, FL (USA) ISSN 0392-6672

https://doi.org/10.5038/1827-806X.46.2.2063

\section{INTRODUCTION}

The presence of chemical deposits in evaporite caves (in particular gypsum caves) was reported since a long time ago (Aldrovandi, 1648; Laghi, 1806; Santagata, 1835; Fedorof, 1883). However, in the second half of the last century, when specific studies on cave mineralogy started (White, 1962; Hill, 1976), evaporite caves were almost completely neglected. Only six cave minerals were known from evaporite cavities at that time: calcite, epsomite, gypsum, halite, ice, and mirabilite. This because chemical deposits in evaporite caves are far less common and often of smaller size respect to those developed within limestone or in even volcanic cavities. Moreover, they exhibit a very low mineralogical variability due to several reasons, especially:

1) calcium sulfate and sodium chloride are by far less reactive than calcium carbonate;

2) evaporite caves have normally a scarce petrographical variability within their recharge areas.

There is no general paper dealing with speleothems developing in halite or anhydrite caves, whereas a review paper on minerals and speleothems in gypsum caves appeared 20 years ago (Forti, 1996).

The mineralogical investigations of a few evaporite karst areas started at the end of the last century; one in halite (Mt. Sedom Israel, Forti \& Buzio, 1985), one in anhydrite (Upper Secchia Valley, Italy; Chiesi \& Forti, 1985), and four in gypsum (Kungur in Russia, and several caves in Emilia Romagna, at Santa Ninfa in Sicily, and Verzino in Calabria, Italy) (Forti, 1986;Volkov et al., 1986; Forti \& Rossi, 1987; Forti \& Lombardo, 1998) but these cover a minimal fraction of the world evaporite outcrops.

Until present only seven karst areas in halite, two in anhydrite and eleven in gypsum (Fig. 1) have been studied for their cave minerals and speleothems, but most of these investigations are only preliminary. 


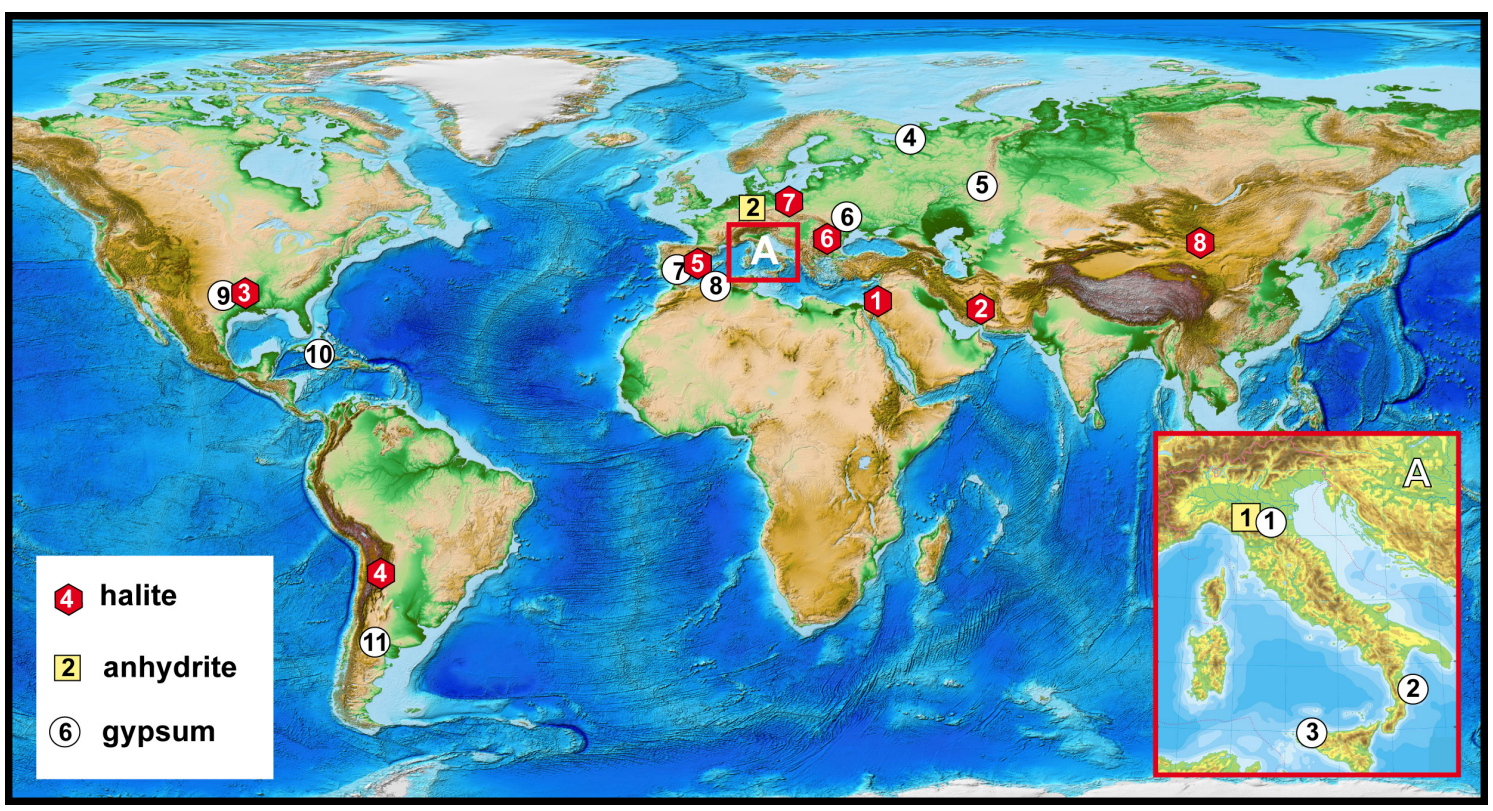

Fig. 1. Location of the evaporite karst areas where speleothems and cave minerals have been at least partially analyzed. Halite: 1) Mt. Sedom, Israel; 2) Central Iran; 3) New Mexico, USA; 4) Atacama, Chile, 5) Cardona, Spain, 6) Mînzălești, Romania, 7) Wieliczka, Poland, and 8) Quinghai China. Anhydrite: 1) Upper Secchia Valley, Italy; 2) Central Germany. Gypsum: 1) Emilia Romagna, Italy; 2) Verzino, Calabria, Italy; 3) Santa Ninfa Sicily, Italy; 4) Pinega (Russia); 5) Kungur, Russia; 6) Podolia, Ukraine; 7) Almeria, Spain; 8) Darhedi, Algeria; 9) New Mexico, USA; 10) Punta Alegre, Cuba; and 11) Neuquén, Argentina.

Nevertheless, these studies highlighted that evaporite caves are environments with peculiar, often exclusive minerogenetic mechanisms, which host extremely rare or even novel cave minerals.

The aim of this paper is to present an updated general outlook on the knowledge on speleothems developing within evaporite caves (halite, anhydrite, and gypsum) in order to foster the interest of cavers and scientists towards this peculiar research area, which undoubtedly will lead to amazing new discoveries in the future.

Speleothem types and cave minerals are described separately for halite, anhydrite, and gypsum caves, because their genetic mechanisms may differ from one lithology to another. Among them, those already described in two previous publications (Forti, 1996; Hill \& Forti, 1997) are only briefly reviewed, while the others are more extensively described, providing additional details on their formation.

\section{HALITE CAVES}

Halite caves are present in many countries of the world, normally under arid climate where rainfall allows their development without causing the salt outcrop to be dissolved too rapidly (Chabert \& Courbon, 1997). Anyway some important halite karst develops also in wetter areas (like Poland and Romania), where the salt bed is protected by a relatively thick impervious cap rock. Morphological and mineralogical observations started within the halite caves of Mt Sedom in the southwestern part of the Dead Sea (Israel) only in the second half of last century (Forti et al., 1984; Forti \& Buzio, 1985; Frumkin \& Forti, 1997). Until present, the chemical deposits of halite caves were at least partially described in eight countries (Israel, Chile, China, Iran, Poland, Romania, Russia, and Spain; Fig. 1) (Müller,
1928; Dzen-Litovsky, 1940; Yuhua \& Lin Hua, 1986; Giurgiu, 1985; Ponta, 1986; Bosák et al., 1999; Cardona \& Vivier, 2002; De Waele et al., 2009a, b, 2016; Filippi et al., 2011; De Waele \& Padovan, 2016), but studied in detail only in three of them (Chile, Iran, and Israel). Nevertheless the halite caves proved to be extremely interesting not only from the mineralogical point of view but also for the richness of peculiar halite speleothem types/subtypes.

\section{Halite speleothems}

The presence of speleothems within halite caves was known since the antiquity; the Incas, and even several hundred years before them, the ancient inhabitants of the Atacama Desert deeply explored the caves to take the extremely pure halite speleothems for domestic use (De Waele et al., 2009a).

Perhaps the first written reference to speleothems is in the "Holy Bible" (Genesis 19, 26). In fact the halite statues near the town of Sodom may be referred to the huge deposits developed inside the caves of $\mathrm{Mt}$ Sedom. Anyway, the first modern report on halite speleothems dates back to the first part of the last century (Dzen-Litovsky, 1940), and refers to several stalactites, stalagmites, and columns found inside a halite cave near Orenburg (Russia).

The single mechanism allowing for the deposition of halite speleothems is evaporation and their shape is strictly controlled by the supersaturation degree of the feeding solution (which may locally be influenced by air currents) and by the flow regime over them (which in turn is heavily affected by rainfalls) (Filippi et al., 2011).

This is the reason why in most of the halite caves the wind-induced forms (anemolites), like trays and rims, are widespread as a direct consequence of the mechanism of halite deposition, which is obviously enhanced by the presence of strong air currents. 
Sprays and aerosols also play an important role sometimes inducing the development of peculiar speleothems like cave fans and coralloids as in the Waterfall Cave in Iran. In fact in this cave there is a rather high $(15 \mathrm{~m})$ waterfall, which, when active, causes, the development of clouds of very fine aerosols and sprays (Filippi et al., 2011). It is evident that the presence of an active waterfall is crucial for the development of such formations, therefore similar, but far less developed, formations have been observed only in the Liquid Crystal cave (Mt. Sedom, Frumkin $\&$ Forti, 1997), while they are totally absent in the Atacama Desert.

Up to present halite cave pearls were never found: the lack of cave pearls is a direct consequence of the long periods without any kind (dripping and/or flowing) of feeding solution into the pools, favoring the evolution of halite crystals and inhibiting the formation of free pearls (Forti \& Buzio, 1985).

Where the water supply and the supersaturation degree are relatively high, the shapes of the halite speleothems (stalactites, soda straws, stalagmites, rimstone dams, and flowstones) are practically similar to the analogous carbonate ones. They consist of several superimposed thin layers inside which the halite micro-crystals are progressively arranged with a vertex pointing towards the growing direction (e.g., the external surface for stalactites, stalagmites and flowstones, or parallel to it in the soda straws, Fig. 2A) (Forti \& Buzio, 1985).

The fact that halite, although isometric, behaves within the speleothem's structure as calcite or gypsum is the direct consequence of the competitive selection among crystals which allows to survive only those oriented exactly exactly along the growing direction (Fig. 2B).

Decreasing the water supply, the inner feeding tube of the halite stalactites and soda straws is progressively filled with halite crystals and their development occurs only by evaporation along their external surface, sometimes giving rise to small halite anthodites. Evaporation along the external surface is also the reason why most of the halite speleothems exhibit external surfaces with botryoidal accretions, and true helictites (with an inner open capillary) are extremely rare, while anthodites (without an inner feeding capillary) are relatively widespread (Hill \& Forti, 1997).

The supply of feeding solutions is crucial for the development of halite speleothems, but Atacama Desert is actually one of the driest place in the world (only a few $\mathrm{mm}$ of rain each year), therefore the hosted formations are rare and normally inactive for centuries, as testified by the perfectly preserved chisel marks over huge halite columns made by Inca miners some 700 years ago (De Waele et al., 2009a). Beside the widespread thin halite crusts developing in the subterranean riverbeds following the extremely rare rainstorms, only in few selected areas of the Atacama caves it is possible to observe active speleothems, the feeding of which is normally induced by short-lived localized enhanced condensation.

Also, Mt. Sedom has a very hot dry climate, with some $50 \mathrm{~mm}$ of rain each year. This amount appears to be enough to allow the development of halite

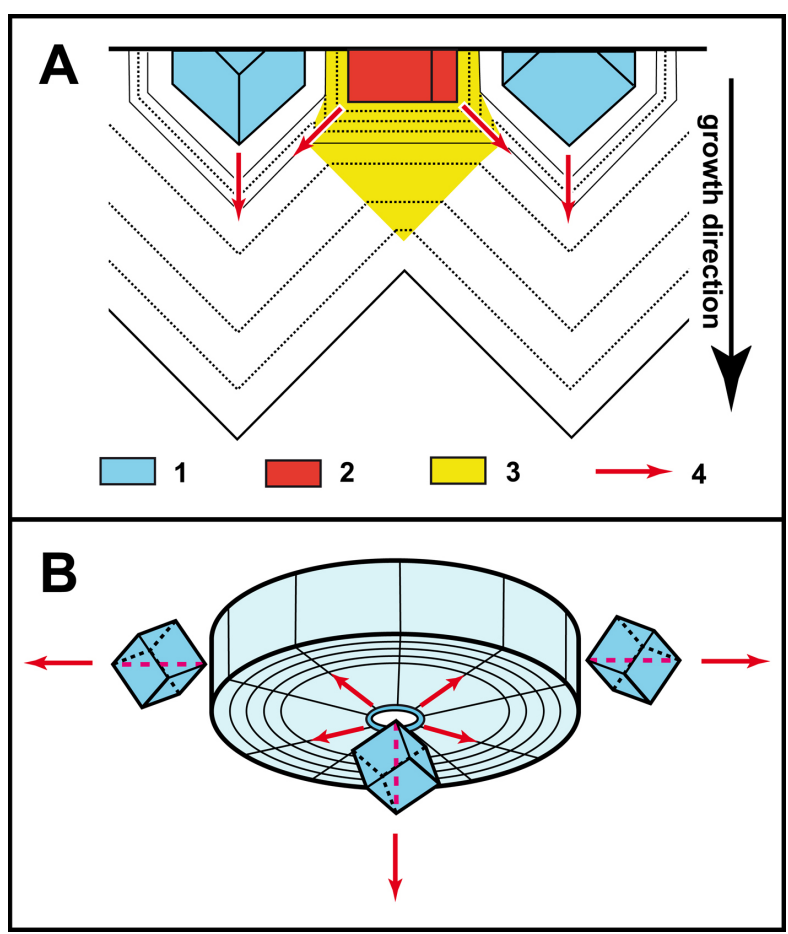

Fig. 2. A) Theoretical section of a stalactite where the preferential orientation of the halite crystals in the radial part and along the feeding tube is evidenced. B) The steric hindrance causes competitive selection among halite crystals so that only those with the long diagonal coincident with the direction of growth may survive (after Forti \& Buzio 1985, modified). 1) Halite crystals with a cube diagonal coincident with the direction of growth; 2) Halite crystal with a face perpendicular to the direction of growth, 3) Area in which the crystal B develops; 4) Area in which only the single crystal lattice of $A$ is present.

deposits, which unfortunately were non systematically investigated over the past 25 years (Forti \& Buzio, 1985, Frumkin \& Forti, 1997).

The best environmental condition for the development of halite speleothems is without any doubt that of the Iranian salt domes, where the average rainfall is $\sim 174$ $\mathrm{mm} / \mathrm{yr}$ with some 15-30 rainy days/year and only one rainstorm every 10 years (Filippi et al., 2011).

Therefore it was possible to systematically describe all the halite speleothems observed in the caves of this area and also to define the factors ruling their evolution. Speleothems were grouped into 4 different classes on the basis of the type of water feeding them: 1) pool and stream water; 2) dripping, splashing and aerosol water; 3) capillary seepage and evaporation water; and 4) "other types" (Filippi et al., 2011). Within these four classes the development and final shape of the different speleothems has been characterized on the basis of some local controlling factors like: flow rate and its variation in time, presence of moist air, evaporation rate and air currents directions.

Finally it was also possible to define the sequence in the development of the different speleothems within the Iranian caves.

Soda straws, macrocrystalline and spray deposits are the first developing after a rain event. Later, when evaporation processes increase their influence, euhedral crystals and rafts form within the pools and microcrystalline speleothems start to develop. The development of the latter is the most perduring process and sometimes it does not interrupt even during dry seasons. 
For a detailed description of all types of halite speleothems (Fig. 3), with special reference to Iran, readers should refer to the excellent paper of Filippi et al. (2011).

In this review only the condition allowing the evolution of macro- \&/or monocrystalline halite formations will be shortly outlined along with three peculiar speleothems up to present restricted to halite caves.

\section{The macrocrystalline speleothems}

Halite has a much higher potential to form macroand/or monocrystalline speleothems than calcite and gypsum. Therefore, in most of the studied halite caves around the world, relatively large euhedral or hopper halite crystals have been observed. The preferential location for these crystals are the pools, where evaporation is sufficiently low to allow the development of euhedral crystals up to $10 \mathrm{~cm}$ in size
(Forti \& Buzio, 1985; Frumkin \& Forti, 1997; Filippi et al., 2011; De Waele et al., 2016).

In the Iranian caves halite macrocrystals normally form also along streams, whereas in the Atacama Desert they are completely lacking. This is because they need time to develop and therefore the stream must remain active for at least a few days (Filippi et al., 2011).

In Atacama, active flow inside the caves exists only for a few hours and only after one of the extremely rare (less than 1 every 10-20 years) rainstorms. Therefore they cannot induce the development of large crystals but they cause the widespread evolution of microcrystalline thin salt crusts due to the extremely fast evaporation of all the available water.

Very large euhedral crystals may grow in hypogenic halite caves, where their development is prompted by the extremely low supersaturation induced by a slight temperature lowering and maintained over an extremely long span of time (Hill \& Forti, 1997).

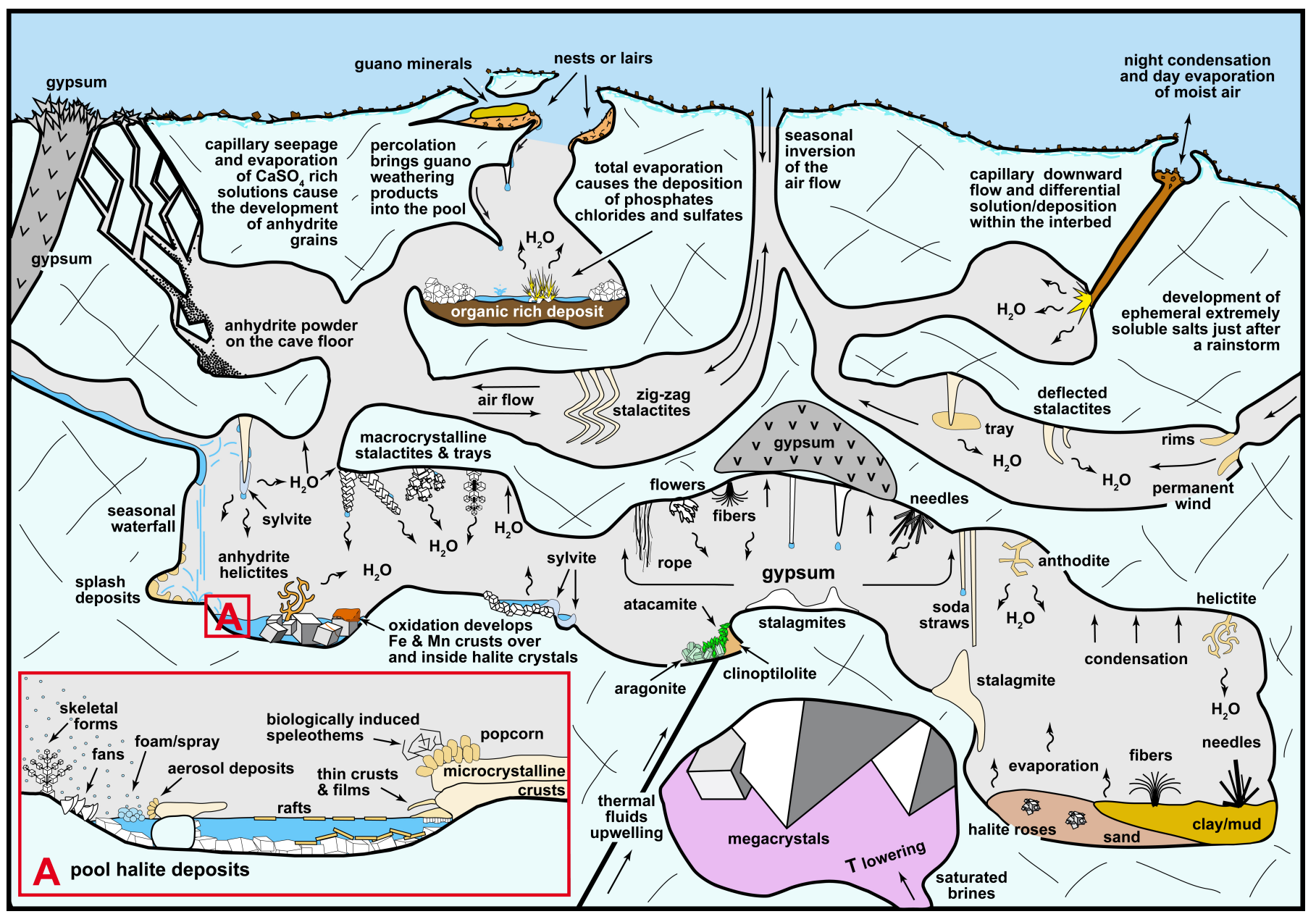

Fig. 3. Diagram summarizing the various types of chemical deposits known from halite caves (if not halite, names of minerals are reported) (inset A is modified after Filippi et al., 2011).

This is the case of the Wieliczka Mine in Poland where at the end of the $18^{\text {th }}$ century, two rather large cavities were intersected during mining works. Their floor, walls, and ceilings were completely covered by euhedral, transparent sparkling halite cubes up to 35 $\mathrm{cm}$ in size. Unfortunately, most of them were removed from these caves and donated to mineralogical museums around the world. However, few such crystals are still visible in these cavities that were later transformed into show caves (Alexandrowicz, 2000). A similar origin is attributed to the human-sized crystals developed in a small halite cavity intercepted within a potash mine near Carlsbad, New Mexico (USA, 3 in Fig. 1) (Komensky, 1966).

Peculiar monocrystalline stalactites are widespread in the Iranian caves; the most common of which are the skeletal ones (Filippi et al., 2011). An idealized skeletal stalactite (Fig. 4A) normally consists of a central rounded "stalactite" from which, at different heights, three smaller and shorter rounded branches develops, being equally spaced at an angle of $120^{\circ}$. Moreover each branch and the central stalactite form 
an angle of $\sim 70^{\circ}$. These values show that the directions of the central columns and the side twigs correspond to that of the four cube diagonals. Finally, at the end of each twig there is a small halite crystal with one of its diagonals perfectly coincident with the twig.

It is therefore evident that the entire structure of these peculiar stalactites consists of a single crystal lattice, albeit with a fractal appearance, and this fact is also confirmed by the presence along the rounded column of evident crystal facets oriented in the same direction. Air currents and other local perturbing factors may cause a deflection from the theoretical direction of both the main column and of the side twigs. Finally the rounded structure of the central column and of the external twigs is normally covered by glazy halite suggesting that cycles of deposition and dissolution alternate, while no inner feeding tube is present within the central column.

On the basis of these observations, the genesis of these skeletal monocrystalline stalactites is induced by solutions mainly coming from brines and sprays that then flow via gravity and capillarity only on the external surface of the stalactites. The amount and the composition of these solutions must change in time, becoming sometimes slightly undersaturated, probably during the rainfalls. The location of these speleothems close to waterfalls, where sprays are easily formed support that idea (Filippi et al., 2011).

A slightly different type of monocrystalline stalactites has been reported from just one cave (Zorro Andina Cave) in the Atacama Desert (De Waele et al., 2009b). The main difference from the Iranian ones is that they completely lack the central glazy cylinder and the side rounded twigs. The morphology of these macrocrystalline stalactites is simpler: in fact they consist only of interpenetrated halite crystals with one of the cube diagonals coincident with the growth direction. Only few of them are straight vertical (Fig. 4C), whereas most are inclined up to $30-50^{\circ}$, a minority of which developed short vertical overgrowths from the lower vertex of each cube (Fig. 4D). Most of these speleothems exhibit clear hopper structure, whilst a few consist of perfect euhedral crystals.

The morphological characteristics of the Atacama stalactites are the direct consequence of the extremely arid climate. In Iran, spray water is fundamental to develop skeletal structures, while in Atacama it is totally absent. In fact in Zorro Andina Cave, the only source of water for the development of these speleothems comes from condensation occurring just in that small portion of the cave and only during a very short period after the rare rainfalls, when the production of spray is uncommon (De Waele et al., 2009b). In these conditions, dripping is less important than capillary seepage and this explains why vertical overgrowth from lower vertices of inclined stalactites are very rare.

Just in a single small roof pocket of Zorro Andina Cave, in the center of the area in which the macrocrystalline stalactites develops, small branched bidimensional skeletal stalactites have been observed (Fig. 4D), the development of which has been related to a strong "sheet" of air flow (De Waele et al., 2009b).
Besides the above described stalactites, there are a few other peculiar monocrystalline halite speleothems worth to be mentioned: halite needles and cave beards: these formations have been reported from all the three studied areas (Atacama, Mt Sedom, and Iran) even if their occurrence is strongly proportional to the available water source: e.g., the highest in Iran and the lowest in Atacama.

These speleothems consist of extremely elongated fibers (ropes may reach even more than $30 \mathrm{~cm}$ in length whith a width of $1 \mathrm{~mm}$ or even less, Hill \& Forti, 1997). They normally develop where deposition occurs from a soft porous substratum (mud, clay, sand, etc.), and each needle \&/or fiber essentially consists of an imperfect halite single crystal stretched in the growth direction (Filippi et al., 2011). Its genesis is induced by the capillary uplift and evaporation of the feeding solution inside the soft sediment and the newly halite deposition always occurs from the bottom of the needle/fiber which is therefore progressively pushed outward.

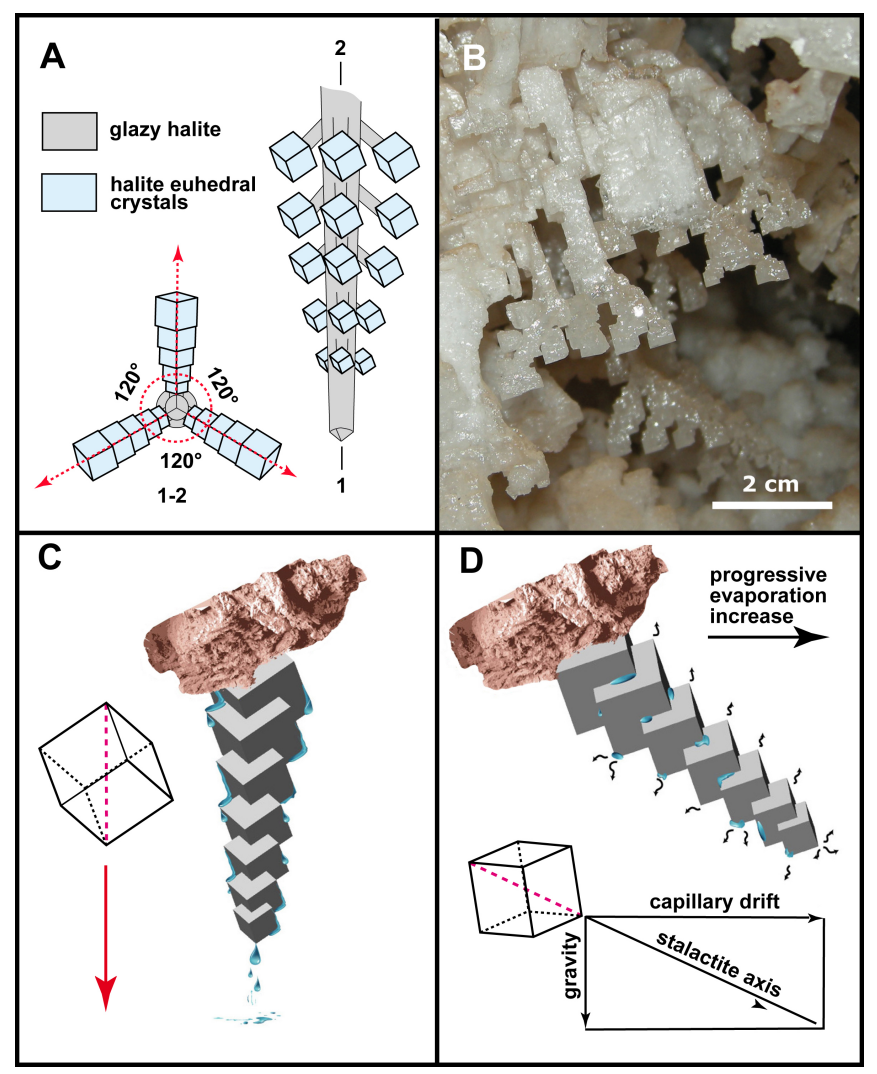

Fig. 4. Macrocrystalline halite stalactites. A) structure of theoretical macrocrystalline stalactite from Iranian caves: side and tip to top views; B: image of bidimensional-pyramid-like trays developed where drip rate is rapid and evaporation suddenly increases due to a "sheet" of airflow; C) Idealized structure of a monocrystalline stalactite from Atacama in absence of airflow ; D) In presence of an airflow gradient the growth axis corresponds to the resultant vector of the gravitational and capillary flows. (A: after Filippi et al., 2011, modified; B,C,D: (after De Waele et al., 2009a, modified).

\section{The microcrystalline speleothems}

Secondary deposits consisting of microcrystalline halite are the most common deposits within the halite caves of all the three investigated areas, even if in the Atacama Desert most of them (beside the crusts along the underground stream and over unconsolidated sediments), are practically inactive for centuries due to its extreme arid climate. 
The microcrystalline speleothems are best displayed in the Iranian caves where it was also possible to describe their evolution phases, which are controlled by the progressive lowering of the feeding water: 1) evolution of compact glazy, often light bluish deposits, 2) deposition of white fine-grained halite and 3) on top evolution of snowy white, loose and small grains forming patchy flowers (Filippi et al., 2011).

Most of the microcrystalline halite speleothems are very similar to those of calcite and/or gypsum even if they are often more botryoidal. Their development is normally induced by capillary transport and therefore it starts when feeding decreases and consequently dripping become less important or completely absent.

Indubitably, the most common speleothems are stalactites that may reach over $3 \mathrm{~m}$ in length in Iran and Mt. Sedom. They are sometimes contorted, furcated, and wind-deflected. Microcrystalline stalagmites are much more rare and relatively more complex requiring in any case some dripping.

Finally the presence of spray and/or aerosol allows the development of microcrystalline speleothems like small curved filamentary anthodites over soda straws (Filippi et al., 2011) or huge complex cottonballs (De Waele et al., 2009a).

\section{Special speleothems}

Besides the above outlined microcrystalline and macrocrystalline formations, halite caves of Iran host also some unique speleothems, which up to present, seem to be restricted to this peculiar evaporite karst environment (Table 1).

\section{The zigzagging stalactites}

Wind-deflected calcite and/or gypsum stalactites are common in limestone and gypsum caves, but in some of the Iranian halite caves they are really unique: the so-called "zig-zag" halite stalactites (Filippi et al., 2011). They consist of a succession of segments alternatively inclined in opposite directions (clearly indicating contrasting airflows present in winter and summer). For such speleothems to develop it is necessary to be fed most of the year and undergo a fast evaporation in a cave area characterized by strong seasonal air currents. Such specific conditions are not easy to be achieved, and for this reason the "zigzagging" stalactites are present only in a couple of Iranian caves. A combination of direct observations and measurements of the increase in length of stalactites and soda straws, suggest that such a halite speleothem may grow up to $50 \mathrm{~cm}$ in one year (Filippi et al., 2011).

\section{The halite roses}

In Iranian caves, the evaporation of brines inside soft sediments (sand or mud), triggers the precipitation of more or less irregular cubes or skeletal formations resembling the renowned gypsum desert roses (Filippi et al., 2011). The shape of the crystals depends on the amount of impurities trapped in the halite lattice, which in turn is influenced by the size of the grains and by the speed of crystal growth.

\section{The biologically-induced speleothems}

Within the Iranian salt caves the extremely fast growth of halite deposits may cause the development of peculiar biologically-induced speleothems covering and completely concealing the original biomasses (Filippi et al., 2011). This is the case of pseudo-anthodites growing on partially germinated seeds and of pseudohelictites/fibers developed over a spider web.

\section{Cave minerals}

Only two halite karst areas have been investigated from the mineralogical point of view: Mt. Sedom in Israel and the Atacama Desert caves in Chile. Nineteen cave minerals are actually known (Table 2) and two of them (antarcticite, and clinoptilolite- $\mathrm{Na}$ ) are novel and restricted to the karst of Atacama (De Waele et al., 2009a, 2016).

Nevertheless, many of the mineralogical groups are represented: sulfates are the largest one with 7 different minerals, followed by halides with 5 and by phosphates with two minerals, while carbonates, nitrates, silicates, and organic compounds are present with only one mineral each.

Most of these minerals (all halides besides atacamite and all sulfates besides leonite and anhydrite powder) were deposited by simple evaporation from brines.

The deposition of the anhydrite and leonite powders and of the new cave mineral antarcticite were also induced by evaporation but under very special boundary conditions (De Waele et al., 2017).

Antarcticite and leonite are extremely soluble, hygroscopic minerals; therefore their formation is extremely difficult even in the very dry environment of the Atacama Desert. Moreover, even if they form, the slightest increase in relative humidity will cause them to dissolve.

The presence of a fine-grained clayey-sandy interbed connecting subsurface open pockets (in which soft sediment accumulates during rainstorms and/or blowing winds) to the cave galleries, along with the extreme aridity of the Atacama climate, are fundamental for the development of these minerals (De Waele et al., 2017). After rare rain episodes, the severe cooling during night (in the Atacama desert it is quite normal to witness a temperature fall of $20^{\circ} \mathrm{C}$ or even more) induces moist air to condense inside the subsurface pockets where $\mathrm{Ca}^{2+}, \mathrm{K}^{+}$ $\mathrm{Mg}^{2+}, \mathrm{SO}_{4}^{2-}$, and $\mathrm{Cl}^{-}$ions are brought into solution. During the day, a partial evaporation causes the deposition of less soluble salts (like halite) thus, allowing a progressive increase in the concentration of the more soluble ones. In the meantime, capillary

Table 1. Speleothem types/subtypes unique to the halite caves and their genetic mechanisms.

\begin{tabular}{|l|c|c|}
\hline \multicolumn{1}{|c|}{ Name } & Genetic mechanism & Reference \\
\hline Zigzagging stalactites & Strong air currents inverting their direction & \multirow{2}{*}{ Filippi et al., 2011 } \\
\hline Halite roses & Growth within soft sandy material & \\
\hline Biologically-induced speleothems & Fast deposition over organic remains & \\
\hline
\end{tabular}


Table 2. List of known cave minerals from halite caves $\left({ }^{*}=\right.$ new for the cavern environment).

\begin{tabular}{|c|c|c|c|c|}
\hline & Name & Chemical formula & Occurrence & First reference \\
\hline 1 & Anhydrite & $\mathrm{CaSO}_{4}$ & $\begin{array}{l}\text { Helictites over halite euhedral } \\
\text { crystals. Subaqueous crusts over } \\
\text { halite Powder filling fractures or } \\
\text { solution pockets. }\end{array}$ & $\begin{array}{l}\text { Forti \& Buzio, } 1985 \\
\text { Frumkin \& Forti, } 1997 \\
\text { De Waele et al., } 2016\end{array}$ \\
\hline 2 & Antarcticite* & $\mathrm{CaCl} \cdot 6 \mathrm{H}_{2} \mathrm{O}$ & $\begin{array}{l}\text { White, ephemeral, millimeter-long } \\
\text { curls on clay-marly substrate }\end{array}$ & De Waele et al., 2016 \\
\hline 3 & Apatite-Cl & $\mathrm{Ca}_{5}\left(\mathrm{PO}_{4}\right)_{3} \mathrm{Cl}$ & $\begin{array}{l}\text { Minor component of whitish deposits } \\
\text { over bird bones }\end{array}$ & De Waele et al., 2016 \\
\hline 4 & Aragonite & $\mathrm{CaCO}_{3}$ & $\begin{array}{l}\text { Crusts up to } 5 \mathrm{~mm} \text { thick of vitreous } \\
\text { luster, transparent to pale-blue or } \\
\text { light-green tabular prismatic crystals }\end{array}$ & De Waele et al., 2009a \\
\hline 5 & Atacamite & $\mathrm{Cu}_{2} \mathrm{Cl}(\mathrm{OH})_{3}$ & $\begin{array}{l}\text { Globular aggregates of emerald green } \\
\text { radial elongated crystals or, rarely, as } \\
\text { millimetric veins of euhedral crystals } \\
\text { within aragonite crusts }\end{array}$ & De Waele et al., 2009a \\
\hline 6 & Barite & $\mathrm{BaSO}_{4}$ & Small micrometric inclusions in halite & De Waele et al., 2016 \\
\hline 7 & Bassanite & $\mathrm{CaSO}_{4} \cdot 0.5 \mathrm{H}_{2} \mathrm{O}$ & $\begin{array}{l}\text { Small fibers in corrosion pockets on } \\
\text { the surface of gypsum crystals }\end{array}$ & De Waele et al., 2016 \\
\hline 8 & Biphosphammite & $\left(\mathrm{NH}_{4}, \mathrm{~K}\right) \mathrm{H}_{2}\left(\mathrm{PO}_{4}\right)$ & Thin small pale yellow layered fibers & De Waele et al., 2009a \\
\hline 9 & Blödite & $\mathrm{Na}_{2} \mathrm{Mg}\left(\mathrm{SO}_{4}\right)_{2} \cdot 4 \mathrm{H}_{2} \mathrm{O}$ & $\begin{array}{l}\text { Granular material in the yellowish } \\
\text { crusts on dried out cave pools }\end{array}$ & De Waele et al., 2016 \\
\hline 10 & Carnallite & $\mathrm{KMgCl}_{3} \cdot 6 \mathrm{H}_{2} \mathrm{O}$ & Crust with prevailing halite $(70 \%)$ & Frumkin \& Forti, 1997 \\
\hline 11 & Celestine & $\mathrm{SrSO} 4$ & $\begin{array}{l}\text { Small micrometric prismatic crystals } \\
\text { in halite }\end{array}$ & De Waele et al., 2016 \\
\hline 12 & Clinoptilolite-Na* & $\mathrm{Na}_{6}\left(\mathrm{Si}_{30} \mathrm{Al}_{6}\right) \mathrm{O}_{72} \cdot 2 \mathrm{OH}_{2} \mathrm{O}$ & $\begin{array}{l}\text { Small whitish to pale-pink earthy } \\
\text { grains with a few euhedral crystals } \\
\text { in pockets and always strongly } \\
\text { associated with halite }\end{array}$ & De Waele et al., 2009a \\
\hline 13 & Darapskite & $\mathrm{Na}_{3}\left(\mathrm{SO}_{4}\right)\left(\mathrm{NO}_{3}\right) \cdot \mathrm{H}_{2} \mathrm{O}$ & $\begin{array}{l}\text { Sub-millimeter laminar crystals in } \\
\text { yellowish crusts on dry cave pools }\end{array}$ & De Waele et al., 2016 \\
\hline 14 & Guanine & $\mathrm{C}_{5} \mathrm{H}_{3}\left(\mathrm{NH}_{2}\right) \mathrm{N}_{4} \mathrm{O}$ & $\begin{array}{l}\text { Earthy, silky-luster milky white to } \\
\text { pale pink crusts }\end{array}$ & De Waele et al., 2009a \\
\hline 15 & Gypsum & $\mathrm{CaSO}_{4} \cdot 2 \mathrm{H}_{2} \mathrm{O}$ & $\begin{array}{l}\text { Beards, anthodites, stalactites. } \\
\text { Transparent cm-size, euhedral } \\
\text { crystals, partially transformed into } \\
\text { bassanite and anhydrite. } \\
\text { Gypsum needles over halite crystals }\end{array}$ & $\begin{array}{l}\text { Frumkin \& Forti, } 1997 \\
\text { De Waele et al., 2009a, } \\
2016 \\
\text { Filippi et al., } 2011\end{array}$ \\
\hline 16 & Halite & $\mathrm{NaCl}$ & $\begin{array}{l}\text { Monocrystalline stalactites. } \\
\text { All kinds of speleothems, euhedral } \\
\text { crystals, zig-zag stalactites, } \\
\text { biologically-induced speleothems }\end{array}$ & $\begin{array}{l}\text { De Waele et al., 2009a, } \\
\text { 2009b; } \\
\text { Filippi et al., } 2011\end{array}$ \\
\hline 17 & Hematite & $\mathrm{Fe}_{2} \mathrm{O}_{3}$ & $\begin{array}{l}\text { Microcrystals in macrocrystalline } \\
\text { stalactites }\end{array}$ & Filippi et al., 2011 \\
\hline 18 & Leonite & $\mathrm{K}_{2} \mathrm{Mg}\left(\mathrm{SO}_{4}\right)_{2} \cdot 4 \mathrm{H}_{2} \mathrm{O}$ & $\begin{array}{l}\text { Small amounts together with } \\
\text { antarcticite }\end{array}$ & De Waele et al., 2016 \\
\hline 19 & Sylvite & $\mathrm{KCl}$ & Pool deposits and rimstone dams & Frumkin \& Forti, 1997 \\
\hline 20 & $\begin{array}{l}\text { Undifferentiated Iron oxides- } \\
\text { hydroxides }\end{array}$ & & $\begin{array}{c}\text { Thin crusts over and inside large } \\
\text { halite crystals }\end{array}$ & Forti \& Buzio, 1985 \\
\hline 21 & $\begin{array}{l}\text { UndifferentiatedManganese } \\
\text { oxides }\end{array}$ & & $\begin{array}{c}\text { Thin crusts over and inside large } \\
\text { halite crystals }\end{array}$ & Forti \& Buzio, 1985 \\
\hline
\end{tabular}

migration inside the interbedded layers prompts further progressive downward concentration until the supersaturation with respect to both antarcticite and leonite is achieved.

Normally this occurs deep inside the interbed. Only during these rare rainstorms the hydraulic pressure allows the supersaturated solution (with respect to antarcticite and leonite) to reach the wall of the cave gallery where evaporation causes their deposition. These two minerals are extremely ephemeral, and are doomed to disappear whenever the relative humidity of the cave air allows the moisture to dissolve them.

The Atacama Desert climate is very dry, with temperatures of $35{ }^{\circ} \mathrm{C}$ in summer and $5^{\circ} \mathrm{C}$ in winter (mean $14{ }^{\circ} \mathrm{C}$ ), an average relative humidity of $40.5 \%$ (minimum 16.7\%, maximum $80.9 \%$ ) and rainfall of 25-50 $\mathrm{mm} \mathrm{a}^{-1}$ (Boschetti et al., 2007). Within the caves, temperatures range between 15 and $18{ }^{\circ} \mathrm{C}$ and the relative humidity is normally very low (around $15 \%$ ) and condensation can be active for only a few days after rainstorms in but a few selected places (De Waele et al., 2017).

Presently no experimental data exist on the stability of these rare minerals in contact with moist air but they were observed over 8 months after a big flood episode, which occurred necessarily just before their genesis. But they remained unaltered for a rather long period thus suggesting that they can survive in areas where air humidity is maintained at low levels. 
The presence of secondary anhydrite in halite caves has been reported previously from Mount Sedom, where anhydrite helictites, euhedral crystals, and subaqueous crusts were found (Forti \& Buzio, 1985; Frumkin \& Forti, 1997), and Atacama, where small crystal aggregates are quite common (De Waele et al., 2009a). It is worth noting that the calcium sulfate that precipitates from saturated $\mathrm{NaCl}$ brines is anhydrite and not gypsum; in fact gypsum (or bassanite) is seldom found inside halite caves.

The development of anhydrite deposits was always related to simple evaporative processes from brines. But in Arco de la Paciencia Cave (Atacama) this mineral occurs as white powder, filling pockets and fractures on the cave walls (De Waele et al., 2017). The anhydrite powders resemble those of gypsum observed in different gypsum caves (Hill \& Forti, 1997), the genesis of which was, depending on location and local climate conditions, controlled by biological digestion of guano, fast evaporation of small water volumes over porous cave walls, or segregation processes induced by freezing. But none of these mechanisms can explain the formation of anhydrite powders in Atacama. In fact, to obtain anhydrite deposits starting from a NaCl-saturated solution with relatively low $\mathrm{Ca}^{2+}$ and $\mathrm{SO}_{4}{ }^{2-}$ concentration, a very slow evaporation is needed in order to avoid foreign ions to be enclosed in the halite crystal lattice. But this mechanism does not explain why the anhydrite forms only small isolated crystals clustered in powdery deposits.

The extreme climate of Atacama is the main factor controlling the development of these powders. Only during rainfall water can infiltrate into halite discontinuities, bringing into solution $\mathrm{Ca}^{2+}$ and $\mathrm{SO}_{4}{ }^{2-}$ from the overlying sediments. After every event the water film along the fractures dries up very slowly and, once pure halite has been deposited, the remaining droplets enriched in $\mathrm{Ca}^{2+}$ and $\mathrm{SO}_{4}{ }^{2-}$, cause the development of small isolated grains of pure anhydrite upon complete evaporation. These dry anhydrite powders can then move through the tiny fracture by means of gravity.

Phosphates (chloroapatite and biphosphammite), nitrates (darapskite), and the organic guanine are the end products of the digestion of bird droppings and/or bones. These are sometimes present in the entrances of the caves or accumulated in pools close to skylights (De Waele et al., 2017). The Fe and Mn oxides/hydroxides were deposited due to (organic or inorganic) oxidation processes of their more soluble reduced sulfates and/or chlorides. Finally the genesis of aragonite, atacamite, and clinoptilolite-Na (new cave mineral) is related to rising thermal fluids along faults intercepted within Chulacao Cave (De Waele et al., 2009a).

\section{ANHYDRITE CAVES}

Anhydrite karst is known from several countries of the world, but in almost all cases it is located at depths that make direct exploration almost impossible (Ford \& Williams, 2007). This is the reason why until present, only caves from two locations (South Harz in Germany and Upper Secchia Valley in Italy, Fig. 1) were explored and their speleothems studied.

The Upper Secchia Valley anhydrite caves and their chemical deposits were already known when the first monograph on speleothems in gypsum caves was published (Forti, 1996). However, at that time these caves were incorrectly considered as formed in gypsum and therefore their deposits were described along with those hosted in classical gypsum karst.

The genesis and evolution of the German and Italian anhydrite caves are completely different; in fact, the first are hypogenic caves (Kempe, 2014) and lack any natural entrance, whereas the second ones are epigenic and often develop very close to the surface (Malavolti, 1949). Therefore, chemical deposits are different in the two locations and restricted to the peculiar environment that controlled the evolution of the caves.

Leaving aside the widespread secondary gypsum produced by the hydration of the host rock, anhydrite caves are extremely poor in chemical deposits. The lack of minerals in the hypogenic ones is because they were filled with stagnant water for most of the time during their development. In the epigenic caves, instead, the absence of cave minerals is mainly attributed to the strong increase in volume caused by hydration of anhydrite (that turns into gypsum), which makes the wall and the ceiling of these cavities extremely fractured. In this latter setting, the rather continuous breakdown normally inhibits the development of even small chemical deposits, which, in any case, are easily washed away by the frequent floods that characterize the Upper Secchia Valley. Despite all these restrictions, the anhydrite caves proved to be interesting not only from a mineralogical point of view, as they host one cave mineral (clinochlore, Chiesi $\&$ Forti, 1985) restricted to this environment, but also for the presence of a unique gypsum/anhydrite speleothem, i.e., the huge "leather like sheets" of Barbarossa Cave (Anonymous, 1988).

\section{Speleothems}

Unlike halite and gypsum caves, which are rich in halite and gypsum formations respectively, anhydrite caves do not host anhydrite speleothems at all. This is a direct consequence of the $\mathrm{CaSO}_{4}-\mathrm{CaSO}_{4} \cdot 2 \mathrm{H}_{2} \mathrm{O}$ solubility disequilibrium, which makes the hydrated mineral (gypsum) less soluble than the anhydrous one (anhydrite) at normal cave temperatures (Hardie, 1967), thus totally hindering the development of secondary anhydrite formations. Most of the gypsum produced by hydration replaces anhydrite within the rock structure and therefore does not form any speleothem. Nonetheless, a minor part of this secondary gypsum may develop some small deposits. In the caves of the Upper Secchia Valley small gypsum crusts and flowstones were observed where condensation water, after dissolving anhydrite, flows over the gallery roof and/or walls where air currents induce evaporation (Chiesi \& Forti, 1988). In the same caves, when per ascensum capillary flow and evaporation are possible, euhedral aggregates of small gypsum crystals may develop on top of rock 
protrusions or over unconsolidated (sand or clay) floor deposits. Gypsum crystals also develop in the German anhydrite hypogenic caves through the same processes (Kupetz \& Knolle, 2015).

\section{A unique gypsum speleothem: the "leather-like" sheets}

The German hypogene anhydrite caves host a strange and peculiar type of gypsum speleothem, the best display of which may be observed in the "Tannery" Room of the Barbarossa show cave, one of the largest anhydrite caves of that area with around $700 \mathrm{~m}$ of development (Kupetz \& Mucke, 1989; Kupetz $\&$ Knolle, 2015). The name "Tannery" was given to this room thanks to the presence of huge (up to over 1 $\mathrm{m}$ long) sheets of gypsum/anhydrite and clay, which hang from the ceiling (Fig. 5).

The evolution of these structures was made possible by the fact that in this area of the cave the subhorizontal anhydrite and plastic clay layers (of no more than $1 \mathrm{~cm}$ in thickness) are alternating (Fig. 5A). Moreover the cave atmosphere is very moist due to the presence of several lakes and therefore condensation occurs over the room ceiling inducing relatively fast anhydrite hydration. Most of the exposed anhydrite is thus transformed into gypsum and consequently the external rock surface undergoes a noticeable increase in volume, which in turn causes the development of a discontinuity between the partially gypsified sheet (roughly $2 \mathrm{~cm}$ ) and the lower still unaltered rock (Fig. $5 \mathrm{~B})$. At this point hydration can proceed along this crack so that the partially detached sheet increases in length and, progressively, bends down due to the plasticity of the clay interbeds (Fig. 5C). The hydration of the exposed fresh surfaces (Fig. 5B) causes the development of new leather-like structures so that the ceiling resembles a puff pastry (Fig. 5D). The thickness of the original anhydrite layers and that of the soft interbedded clay seems to be the controlling factors for the development of this strange speleothem. This is confirmed by the fact that in other caves of the same area where anhydrite layers are thicker, the formation of leather-like speleothems is less well developed.

In the Upper Secchia Valley, where anhydrite beds are always several centimeters thick and the interbedded clay layers extremely rare, no sheets at all were ever observed.

\section{Cave minerals}

Anhydrite caves host only nine minerals (Table 3), but one of them (clinochlore) was never reported from a different cave environment (Hill \& Forti, 1997) and it is still restricted to just one cave in the Upper Secchia Valley (Chiesi \& Forti, 1985).

The large majority of observed cave minerals (8) were found in the caves of the Upper Secchia Valley, while only one (dolomite) is unique to the Harz caves.

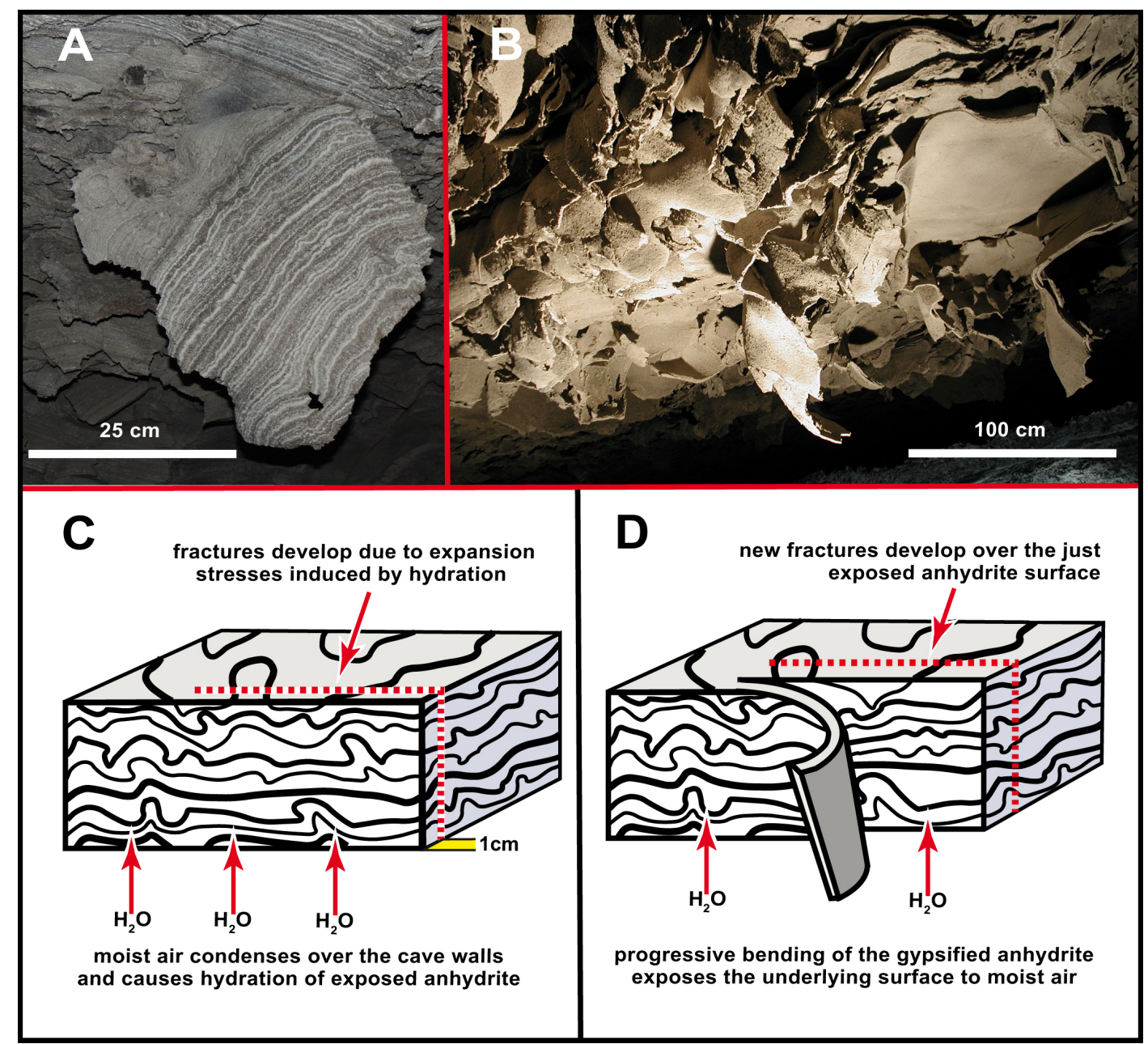

Fig. 5. Genetic mechanism for the development of leather-like sheets. Hydration and consequent expansion of the exposed anhydrite beds detaches a thin layer from the cave wall (A) and a first leather-like sheet develops (B), while the process restarts for the development of a second one. C) The thin laminated structure of the anhydriteclay beds, and D) The best display of leather-like sheets in the Barbarossa Cave (photos by S. Kempe). 
Table 3. List of known minerals from anhydrite caves $\left({ }^{*}=\right.$ new mineral for the cave environment and exclusive to anhydrite caves).

\begin{tabular}{|c|c|c|c|c|}
\hline & Name & Chemical formula & Occurrence & First reference \\
\hline 1 & Brochantite & $\mathrm{Cu}_{4}\left(\mathrm{SO}_{4}\right)(\mathrm{OH})_{6}$ & $\begin{array}{l}\text { Emerald green crusts associated with } \\
\text { devilline and clinochlore }\end{array}$ & $\begin{array}{l}\text { Chiesi \& Forti, } \\
1985 \\
\end{array}$ \\
\hline 2 & Calcite & $\mathrm{CaCO}_{3}$ & $\begin{array}{l}\text { Large flowstones in the riverbeds, } \\
\text { small and rare stalactites or soda } \\
\text { straws. } \\
\text { Microcrystals in "dolomitic ashes" } \\
\text { together with dolomite and gypsum }\end{array}$ & $\begin{array}{l}\text { Chiesi \& Forti, } \\
1988 \\
\text { Kupetz \& Knolle, } \\
2015 \\
\end{array}$ \\
\hline 3 & Clinochlore * & $\mathrm{Mg}_{5} \mathrm{Al}\left(\mathrm{AlSi}_{3} \mathrm{O}_{10}\right)(\mathrm{OH})_{8}$ & $\begin{array}{c}\text { Small acicular crystals in emerald } \\
\text { green crusts of brochantite and } \\
\text { devilline }\end{array}$ & $\begin{array}{l}\text { Chiesi \& Forti, } \\
1985\end{array}$ \\
\hline 4 & Devilline & $\mathrm{CaCu}_{4}\left(\mathrm{SO}_{4}\right)_{2}(\mathrm{OH})_{6} \cdot 3 \mathrm{H}_{2} \mathrm{O}$ & $\begin{array}{l}\text { Crusts of vitreous luster } \\
\text { transparent to pale-blue or light-green } \\
\text { tabular prismatic crystals }\end{array}$ & $\begin{array}{l}\text { Chiesi \& Forti, } \\
\quad 1985\end{array}$ \\
\hline 5 & Dolomite & $\mathrm{CaMg}\left(\mathrm{CO}_{3}\right)_{2}$ & $\begin{array}{l}\text { Microcrystals in "dolomitic ashes" } \\
\text { together with calcite and gypsum }\end{array}$ & $\begin{array}{l}\text { Kupetz \& Knolle, } \\
2015\end{array}$ \\
\hline 6 & Gypsum & $\mathrm{CaSO}_{4} \cdot 2 \mathrm{H}_{2} \mathrm{O}$ & $\begin{array}{l}\text { Small crusts and crystals. } \\
\text { Microcrystals in "dolomitic ashes" } \\
\text { together with calcite and dolomite }\end{array}$ & $\begin{array}{c}\text { Chiesi \& Forti, } \\
1986 \\
\text { Kupetz \& Knolle, } \\
2015\end{array}$ \\
\hline 7 & Ice & $\mathrm{H}_{2} \mathrm{O}$ & $\begin{array}{c}\text { Huge ephemeral stalactites and } \\
\text { flowstones }\end{array}$ & $\begin{array}{c}\text { Chiesi \& Forti, } \\
1986 \\
\end{array}$ \\
\hline 8 & Magnesite & $\mathrm{MgCO}_{3}$ & Small crystals in soft sediments & $\begin{array}{l}\text { Bertolani \& Rossi, } \\
1986\end{array}$ \\
\hline 9 & Opal & $\mathrm{SiO}_{2} \cdot \mathrm{nH}_{2} \mathrm{O}$ & $\begin{array}{l}\text { Thin crusts and coralloids within soft } \\
\text { layers of } \mathrm{Fe} \text { oxides/hydroxides }\end{array}$ & $\begin{array}{c}\text { Chiesi \& Forti, } \\
1986 \\
\end{array}$ \\
\hline 10 & $\begin{array}{l}\text { Undifferentiated Iron oxides } \\
\& \text { hydroxides }\end{array}$ & & $\begin{array}{l}\text { Soft brown layers alternated with } \\
\text { white calcite layers in a stalactite }\end{array}$ & $\begin{array}{l}\text { Chiesi \& Forti, } \\
1986 \\
\end{array}$ \\
\hline 11 & Undifferentiated Mn oxides & & $\begin{array}{l}\text { Crust with prevailing Fe oxides/ } \\
\text { hydroxides }\end{array}$ & $\begin{array}{l}\text { Chiesi \& Forti, } \\
1986\end{array}$ \\
\hline
\end{tabular}

Gypsum and calcite are the only minerals developing at both sites even though their morphology and genesis are often quite different.

Four mineralogical groups are represented in the caves of the Upper Secchia Valley (Table 3): sulfates are the largest one with three minerals, followed by carbonates and silicates, with two minerals. Oxides are represented only by undifferentiated oxides-hydroxides.

Besides gypsum, two copper sulfates have been reported (Chiesi \& Forti, 1985): brochantite and devilline. These two copper minerals were observed mingled together in a thin emerald green crust in the Monte Rosso resurgence cave. Their genesis is related to the oxidation of rare chalcopyrite crystals dispersed within the anhydrite rock.

Among the oxides, ice forms very large ephemeral deposits during winter, such as the several meter long stalactites and draperies in Tanone Grande della Gaggiolina Cave.

Iron and manganese oxides are widespread in many of the caves of this area but never form crystalline structures and rarely develop true speleothems. Normally they are present as thin terrigenous soft layers inside calcite formations, as in the Inghiottitoio dei Tramonti (Sunset Sinkhole). Their origin has been related to pedogenetic processes induced by anthropic deforestation (Chiesi \& Forti, 1986).

Calcite is by far the most common mineral in the Upper Secchia Valley caves, forming huge flowstones along the main subterranean stream passages, as a result of incongruent dissolution of anhydrite by $\mathrm{CO}_{2}$ rich seeping waters. The development of stalactites and draperies follows the same genetic mechanisms, are very rare and small, due to the instability of the cave roof and walls.

The second carbonate, magnesite, was found only within the Tanone Grande della Gaggiolina cave as a minor component in a sandy-clay deposit. The genesis of the small euhedral crystals of magnesite was stimulated by the total evaporation of interstitial Mg-rich water coming from the dissolution of primary dolomite dispersed in the anhydrite beds (Bertolani $\&$ Rossi, 1986).

Opal was found as thin crusts and coralloids inside the soft layers of $\mathrm{Fe} / \mathrm{Mn}$ oxides/hydroxides in the calcite speleothems of the Inghiottitoio dei Tramonti. Its deposition was likely controlled by the lowering of the $\mathrm{pH}$ caused by oxidation of the iron and manganese compounds.

Finally the last silicate, clinochlore, is a new cave mineral unique to the anhydrites of the Upper Secchia Valley. It has been found as microscopic acicular crystals dispersed in the emerald green crusts composed of devilline and brochantite in the Monte Rosso resurgence. Its origin is probably related to the reaction between the sulfuric acid (resulted from sulfide oxidation) and clays (Chiesi \& Forti, 1985).

\section{Dolomite ashes}

Beside the leather-like sheets, the only chemical deposits developed inside the German caves are the so called "dolomite ashes" (Kupetz \& Knolle, 2015). This name was given by the copper shale miners to those powdery deposits often observed inside the anhydrite caves intersected during mine activities that date back to the $17^{\text {th }}$ century. They consist of an admixture of residual material (dolomite and calcite 
grains from the underlying carbonate formations and clay from the insoluble interbeds exposed on the surface of the anhydrite rock) and diagenetic small euhedral crystals of calcite, dolomite, and gypsum (Kupetz \& Knolle, 2015). Since these powders were first observed and until a detailed mineralogical and morphological analysis was performed, they were largely regarded as carbonatic remnants.

The genesis of dolomite ashes is strictly related to the genesis of the anhydrite caves of that area. In fact, they were formed just when the $\mathrm{Ca}^{2+}, \mathrm{Mg}^{2+}$, and $\mathrm{HCO}_{3}^{-}$rich waters, coming from the underlying carbonate formations, started solubilizing anhydrite thus creating the hypogenic caves (Fig. 6A).

But the process of sulfate dissolution triggered a supersaturation with respect to calcium and magnesium carbonates, inducing further incongruent dissolution of anhydrite with simultaneous deposition of prevailing dolomite and calcite (Fig. 6B). This process went on as long as the caves were filled with
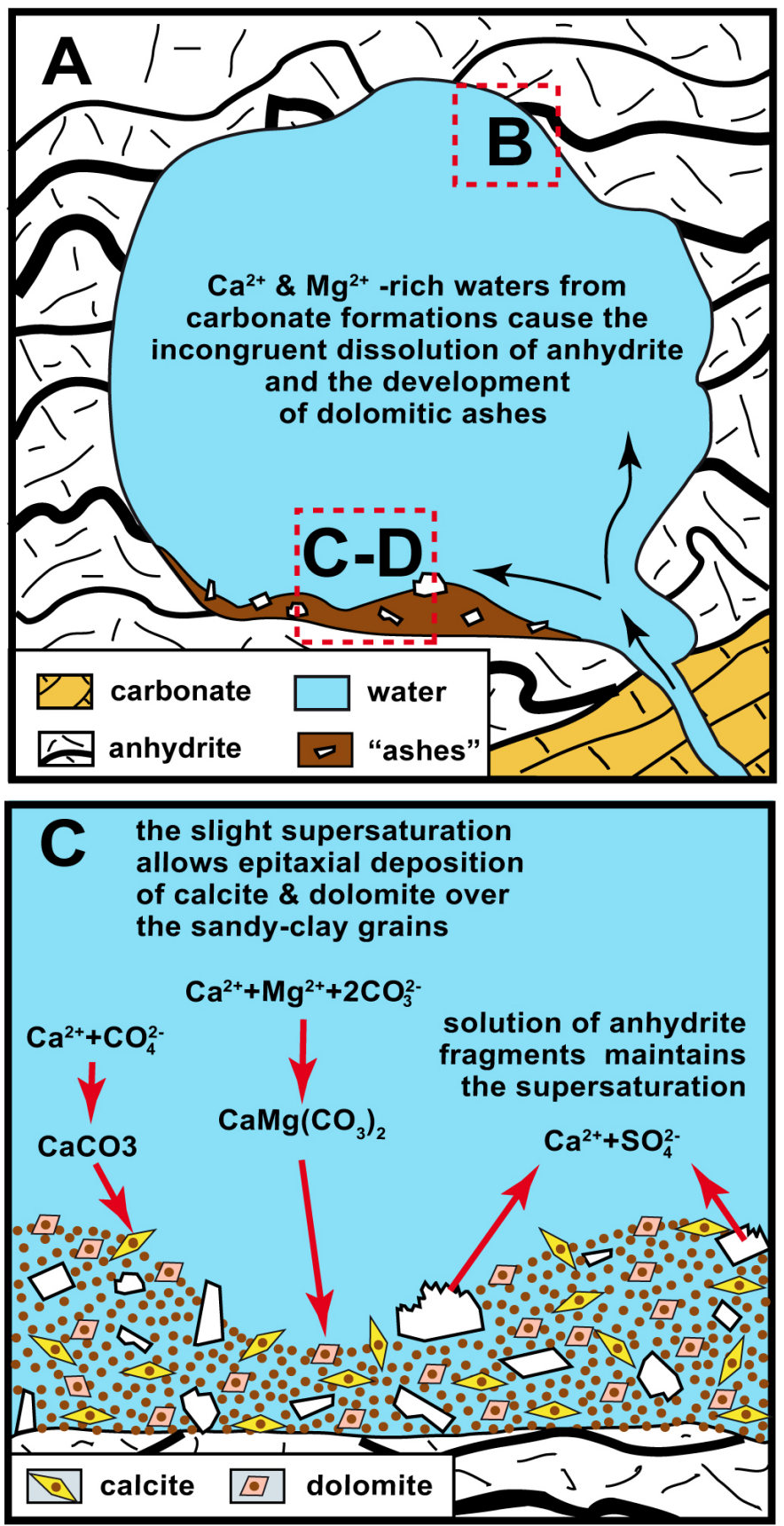

Fig. 6. Genetic mechanisms for the development of dolomite ashes. water and rising flow from the underlying formations was active. Dissolution of the anhydrite layers allowed the insoluble impurities (mainly clay particles from within anhydrite, but also remnants of the underlying formations) to settle along with the newly formed dolomite and calcite (Fig. 6C). It is possible that some of the rare gypsum crystals present in the dolomitic ashes were partially deposited during the dissolution of the anhydrite, due to the solubility disequilibrium which makes the hydrated sulfate (i.e., gypsum) less soluble than the anhydrous one (Hardie, 1967). Nevertheless, it is much more probable that gypsum started developing when these caves became vadose and condensation/evaporation processes were active (Fig. 6D).

\section{GYPSUM CAVES}

In the only general paper dealing with chemical deposits in gypsum caves (Forti, 1996) there is the
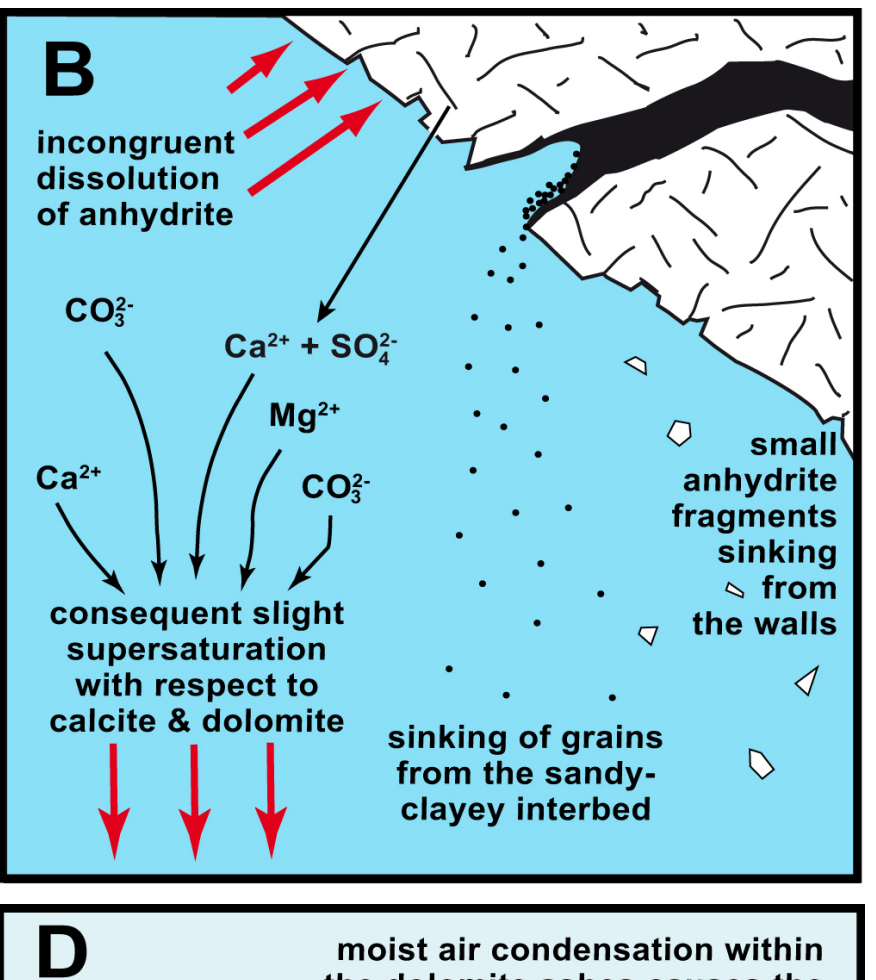

moist air condensation within the dolomite ashes causes the dissolution of anhydrite fragments

capillary rise and evaporation

induce the deposition of gysum

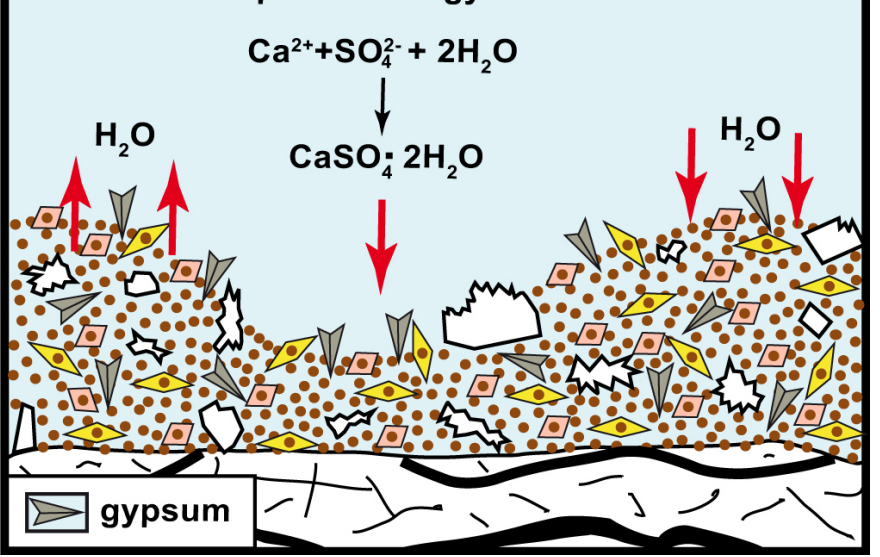


following statement: “... Speleothems are generally uncommon in gypsum caves and therefore papers discussing the genesis of the chemical deposits in these caves are rare. Recently a study has begun on gypsum karst in different climatic zones around the world ..., though as yet the distribution of this research coverage is patchy, or it is only partially complete...", which unfortunately, twenty years later is still valid.

Although there is a generally-accepted view that gypsum karst may host unique speleothems and new cave minerals, only very few researches have been performed, and no additional studies were carried out in previously poorly investigated gypsum karst areas.

To date, eleven regions representing less than $10 \%$ of world's gypsum karst areas (Fig. 1), received various degrees of scientific attention; these are perhaps enough to represent the different climatic zones of our planet, but certainly, future additional coverage will improve our understanding of chemical deposits in gypsum caves. Many curious calcite and/ or gypsum speleothems have been observed and 27 different cave minerals, four of which (buserite, chloromagnesite, gaylussite, and howlite), exclusive of this environment, and 3 undifferentiated groups have been described from these caves (Fig. 7).

\section{Speleothems}

The presence of speleothems within gypsum caves was already documented some centuries ago; the first description of them belongs to Ulisse Aldrovandi (1648) in his "Musaeum Metallicum", where a calcite stalactite from a gypsum cave near Bologna was described with the name of "stelechite" (from the ancient Greek word oi $\eta$ $\varepsilon \kappa o s$ meaning trunk).

In the same book, a large euhedral gypsum crystal found in a natural cavity of the same area is also described.

Following the structure of Forti's (1996) first overview on this topic, calcite and gypsum speleothems will be discussed separately, and those described in that paper will only be summarized here; for their full description, readers should refer to that paper.

\section{Calcite speleothems}

Calcite speleothems are common in gypsum caves and their development is strictly controlled by climate, the maximum development occurring in temperate continental and tropical rainy areas (Calaforra et al., 2008; Columbu et al., 2015). The normal process ruling calcite deposition is the incongruent dissolution of gypsum (Forti \& Rabbi, 1981). The diffusion of $\mathrm{CO}_{2}$ in the cave atmosphere may play a role in the development of calcite speleothems only when percolation waters cross carbonate sequences before surfacing in the cave. Finally, when strong evaporation occurs, the reverse phenomenon (i.e., the diffusion of $\mathrm{CO}_{2}$ from the cave air into a gypsum saturated solution) could favor the development of calcite rafts (Forti, 2003).

In gypsum karst the calcite speleothems normally grow faster than in limestone caves (up to $1 \mathrm{~mm} /$ year, Dalmonte \& Forti, 1995): this is because the efficiency of the incongruent solution is very high with respect to the normal $\mathrm{CO}_{2}$ diffusion. Locally,

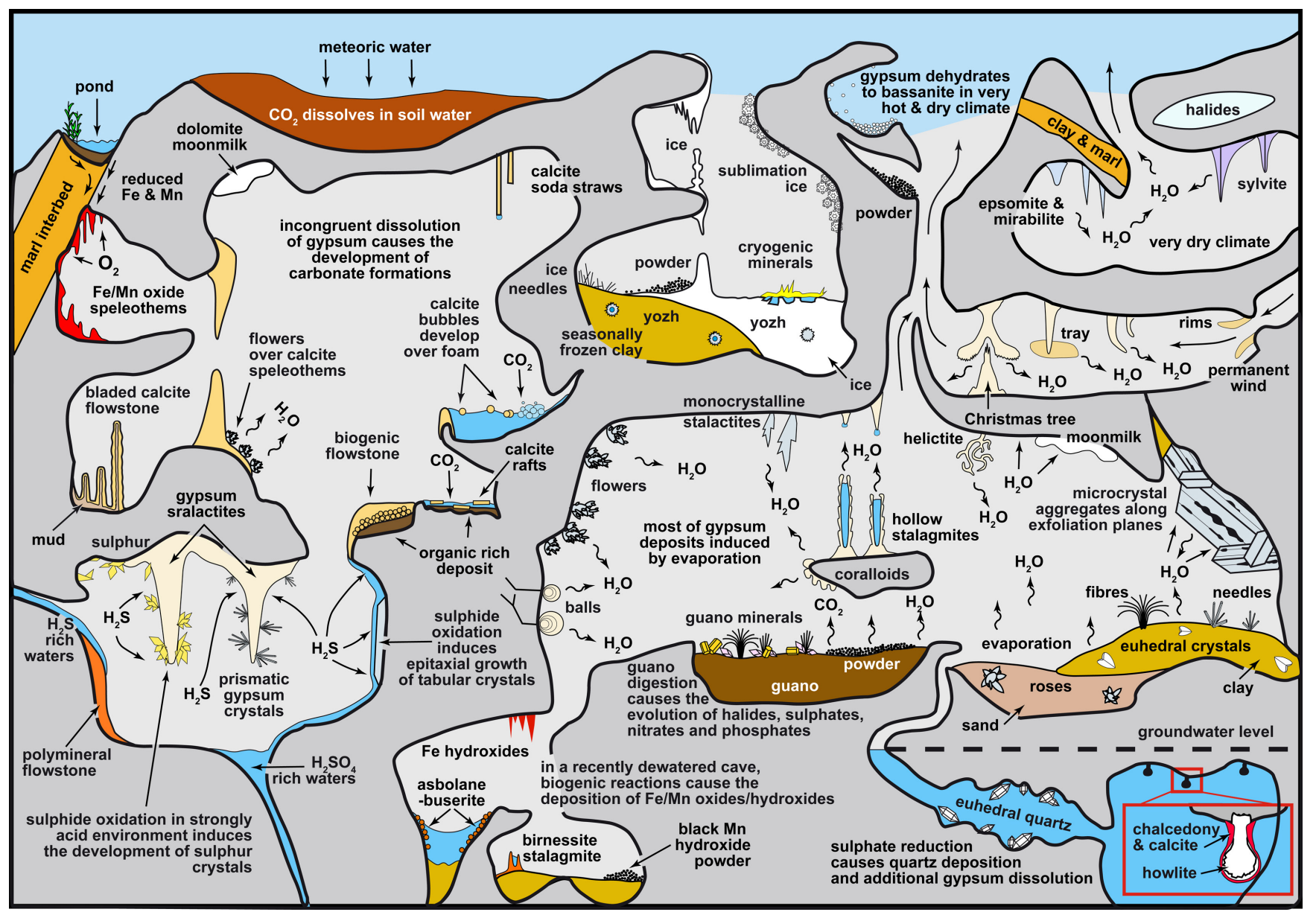

Fig. 7. Diagram of different types of chemical deposits known to occur in gypsum caves. 
the evolution of calcite speleothems is also strictly controlled by the water-feeding regime, so that the same rainfall may induce opposite processes over active calcite speleothems in the same karst area: in fact some of these formations will grow while others will be corroded (Dalmonte et al., 2003). Corrosion is restricted to the speleothems growing very close to the external surface (from 1-2 to a maximum of 10-15 meters below), whereas speleothems forming further below surface are unaffected and continue to grow. This is because during rainstorms, the very short contact time between seeping water and gypsum rock inhibits the complete reaction between dissolved $\mathrm{CO}_{2}$ and gypsum so that when these waters reach the first speleothems they are still aggressive with respect to calcite and therefore they are partially corroded. Corrosion may also occur during long dry periods, when condensation waters can form directly on calcite speleothems.

Finally, in gypsum caves developed close to the surface, a single rain event sometimes induces the growth of a new calcite layer instead of causing the thickening of the previous one, so that in a given speleothem a single year may correspond to dozens of growth laminae (Cazzoli et al., 1988). This depends on the fact that in gypsum caves lying close to the external surface (like those of Emilia Romagna and/or Sicily in Italy), meteoric water seepage is very fast so that feeding water stops flowing over calcite speleothems within few days after the rain event. If the time period between subsequent rains is long enough, the external speleothem surface becomes completely dry and a new rain will cause the development of a new growth lamina. In conclusion, at least theoretically, a new growth layer potentially may develop after each dry interval between rainfalls or rainfall periods: that is the case of a calcite formation developed over nylon wire left for 20 years over an active flowstone in the Acquafredda Cave (near Bologna), which reveals the presence of over 500 layers (Cazzoli et al., 1988).

Carbonate stalactites, flowstones, splash forms and cave pearls are the most common speleothems, and they show no morphological differences with respect to those in limestone caves (Maksimovich, 1969). However, a few calcite speleothems that are special to gypsum environments exist.

\section{Unique carbonate speleothems in gypsum caves}

Besides the normal calcite speleothems, gypsum caves host some unique ones which, up to present, seem to be exclusive to this environment. In particular the bladed speleothems, the bubbles, the half-bubbles, the $\mathrm{CO}_{2}$ solution-induced rafts and the biological flowstones (Table 4). All of these are controlled by the solubility disequilibrium among calcite and gypsum but only one (bladed flowstones) is directly produced by incongruent dissolution, while the other four (bubbles, half bubbles, rafts, and biogenic flowstone) are the result of the increase in dissolved $\mathrm{CO}_{2}$.

Table 4. Calcite speleothem types/subtypes unique to the gypsum caves and their genetic mechanisms.

\begin{tabular}{|l|c|c|}
\hline \multicolumn{1}{|c|}{ Name } & Genetic mechanism & Reference \\
\hline Bladed flowstones & Incongruent dissolution of gypsum & Forti \& Rabbi, 1981 \\
\hline Bubbles & $\mathrm{CO}_{2}$ diffusion from a steady foam in organic-rich water & Ercolani et al., 2013 \\
\hline Half bubbles & $\mathrm{CO}_{2}$ diffusion from a steady foam in organic-rich water & Forti \& Chiesi, 1995 \\
\hline Rafts & $\mathrm{CO}_{2}$ solution from cave atmosphere & Forti, 2003 \\
\hline Biogenic flowstone & Breathing of living organisms & Poluzzi \& Minguzzi, 1998 \\
\hline
\end{tabular}

\section{Bladed flowstones}

Incongruent dissolution causes the development not only of the "normal" calcite speleothems but is also responsible for the development of thin calcite crusts almost completely detached from the strongly dissolved gypsum wall and for the genesis of huge (up to $14 \mathrm{~m}$ high and $3 \mathrm{~m}$ wide, but only $10 \mathrm{~cm}$ thick) bladed flowstones (Fig. 8A) with mud nuclei in the gypsum caves of Italy and Cuba (Forti \& Rabbi, 1981; Chiesi et al., 1992). Their development starts when water flows over a subvertical wall dissolving the gypsum and leaving an insoluble clay residue behind, while simultaneously depositing a calcite flowstone upon the clay. As gypsum dissolution continues, the flowstone also covers the other side of the clay and remains detached from the wall (Fig. 8B), thus becoming a bladed flowstone (Fig. $8 \mathrm{C}$ ). The same process may be repeated several times until a series of thin blades parallel to the retreating gypsum wall is left (Fig. 8D).

\section{Bubbles}

These speleothems have been observed recently in two caves of Emilia Romagna (Grotta Grande dei Crivellari and Abisso Mornig, Italy (Ercolani et al., 2013). They consist of small, sometimes perfectly rounded, empty calcite shells (with a diameter ranging from 2 to 7-9 $\mathrm{mm}$ and their wall constantly $\sim 0.1 \mathrm{~mm}$ thick), which only develop over occasionally submerged gypsum boulders along a subterranean river with organic-rich waters (Fig. 9A). These speleothems are very delicate and therefore their existence is ephemeral; in fact, if the boulder is flooded all bubbles are destroyed.

Their genesis is controlled by the presence of organic matter in the water, the oxidation of which causes the development of long-lasting foam bubbles, inside which the produced $\mathrm{CO}_{2}$ reacts with the $\mathrm{Ca}^{2+}$ and $\mathrm{SO}_{4}{ }^{2-}$ saturated solution thus causing the development of very small calcite cave rafts on the outer surface of the foam bubble (Fig. 9B). Gravity progressively accumulates these rafts in the lower part of the foam bubble, where they cement to each other thus developing the outer shell of a calcite bubble, which later may become empty of water.

\section{Half bubbles}

This rare calcite speleothem has been described in only one cave (Grave Grubbo, Calabria, Italy; Forti \& Chiesi, 1995) and it is a sub-type of calcite bubbles 


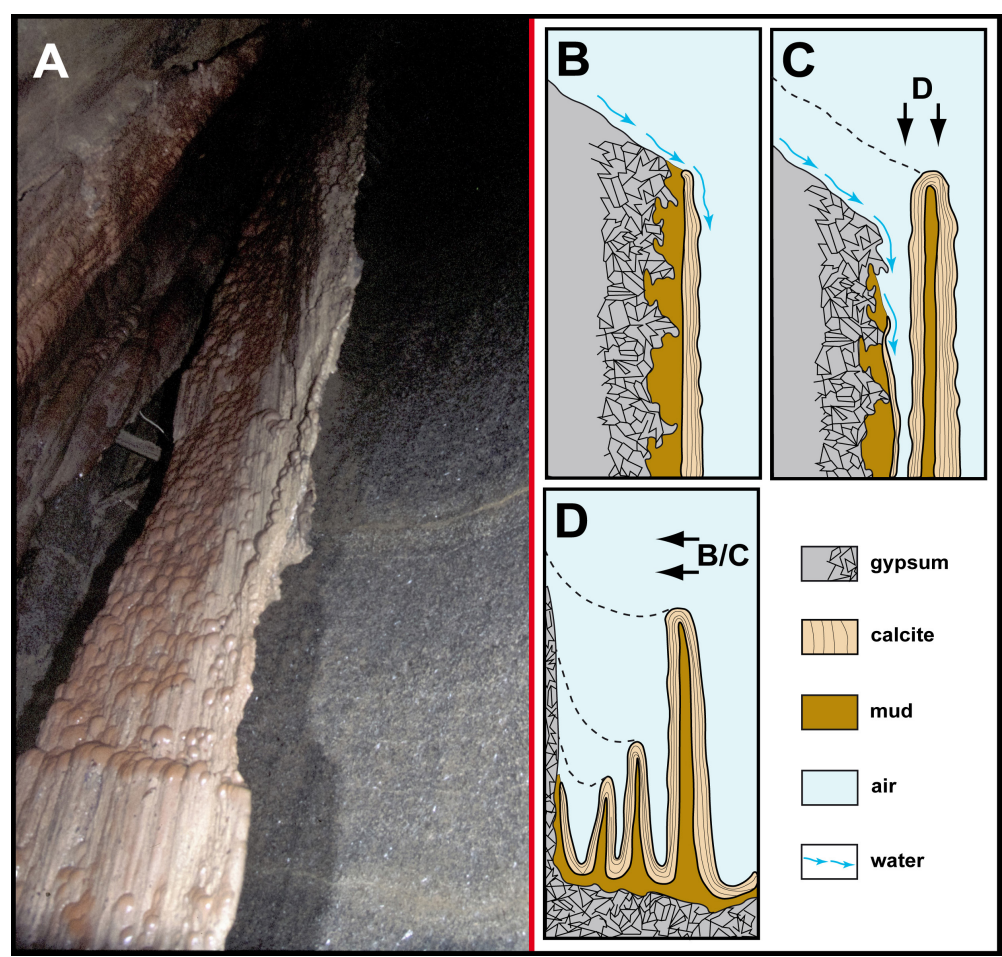

Fig. 8. Novella Cave (Bologna, Italy). A) The largest bladed calcite flowstone (12 m high, $2.5 \mathrm{~m}$ wide and only $0.15 \mathrm{~m}$ thick), the solution of gypsum caused a retreat $(\sim 2 \mathrm{~m})$ of the wall over which the speleothem developed (photo Sandro Mandini, Gruppo Speleologico Bolognese); B) Seeping water causes the incongruent dissolution of the gypsum wall and the deposition of calcite flowstone; C) The retreat of the wall induces the evolution of a first calcite-bladed flowstone; D) As this process continues, it leads to the development of a series of subparallel calcite-bladed flowstones.

(Fig. 9C). This speleothem consists of multiple calcite half bubbles, from 2 to $12 \mathrm{~mm}$ in diameter cemented to each other and floating on a pool surface. The "half bubbles" form in a similar way to the bubbles, but in this case the process is interrupted by splashes before the bubbles become totally hardened. Thus, when impacted by a droplet, the upper part of the still unconsolidated bubble eventually breaks, leaving the "calcite half bubbles" floating on the pool's water surface.

\section{Rafts}

When pools are filled with gypsum-saturated waters and there is a lack of recharge for a relatively long time interval, the evaporation leads to the development of rafts (Fig. 10) in which calcite largely prevails over gypsum (Forti, 2003).

This occurs because the $\mathrm{CO}_{2}$ needed to induce $\mathrm{CaCO}_{3}$ deposition is continuously supplied by diffusion from the cave atmosphere into the solution, which undergoes a simultaneous $\mathrm{Ca}^{2+}$ depletion. Therefore, even if evaporation continues, the supersaturation with respect to gypsum is reduced to a minimum, and is practically never reached.

In areas where the climate does not allow high $\mathrm{CO}_{2}$ content in the cave atmosphere, this phenomenon does not occur: this is the case of the Park's Ranch Cave (New Mexico), where gypsum (and not calcite) rafts cover inactive pools along the underground stream (Onac, pers. comm.).

\section{Biogenic flowstone}

As the just described half bubbles, also this speleothem is exclusive to Grave Grubbo Cave
(Poluzzi \& Minguzzi, 1998). It consists of a 50 $\mathrm{cm}$ thick, $2 \mathrm{~m}$ wide calcite flowstone developed on top of a small waterfall. In a few points, this speleothem was broken, revealing its internal structure, which consists of an aggregate of equidimensional tubes $(0.3-0.5 \mathrm{~cm}$ in diameter $)$ with an external wall of $1 \mathrm{~mm}$ comprised of several thin superimposed layers. The structure suggests a biogenic origin, and appears to be related to the widespread presence of larvae of a troblobitic insect (Trichoptera wormaldia) living over masses of organic waste (Poluzzi \& Minguzzi, 1998). The mechanism involved in biogenic flowstone development is similar to the one of the half bubbles, but the source of $\mathrm{CO}_{2}$ is the biological activity of the larvae. The progressive deposition of calcite occurred upon the larvae due to the supersaturation induced by the $\mathrm{CO}_{2}$ produced by breathing in gypsumsaturated water; this explains why the tubes all have the same diameter, corresponding to the size of the larvae itself. The thickness of each calcite tube is almost constant ( 0.3$0.4 \mathrm{~mm}$, corresponding to $3-5$ calcite layers) because the biological activity of the larvae reduced drastically and eventually terminated, when the calcite deposit covering the animals exceeded this critical thickness (Forti \& Lombardo, 1998).

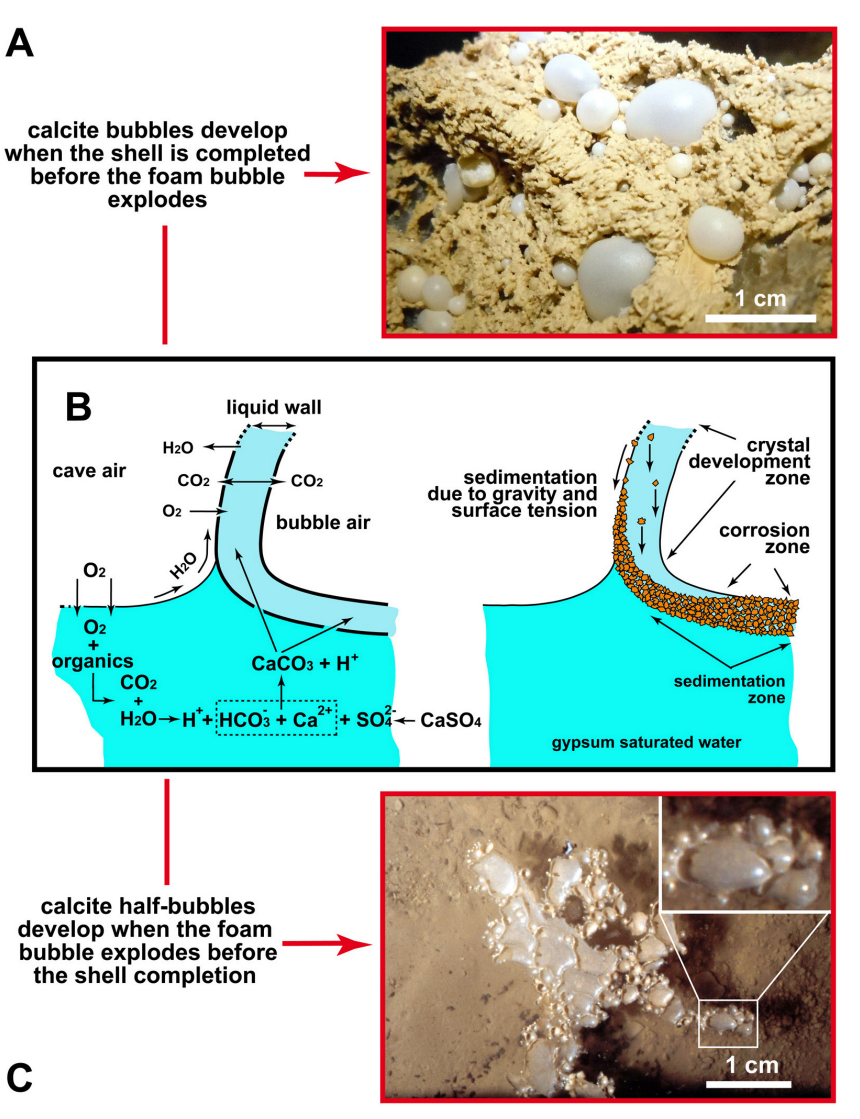

Fig. 9. Carbon dioxide diffusion and evaporation induce the development of calcite rafts along the upper part of each bubble in the foam (B). These rafts sink by gravity in the lower part of the bubble where they consolidate forming a calcite shell. If the shell is completed, a calcite bubble develops (A) (photo by Davide Del Borgo, Gruppo Speloelogico Faentino), but when the foam bubbles break before their complete consolidation, floating half-bubbles form (C) (photo by Paolo Forti). 


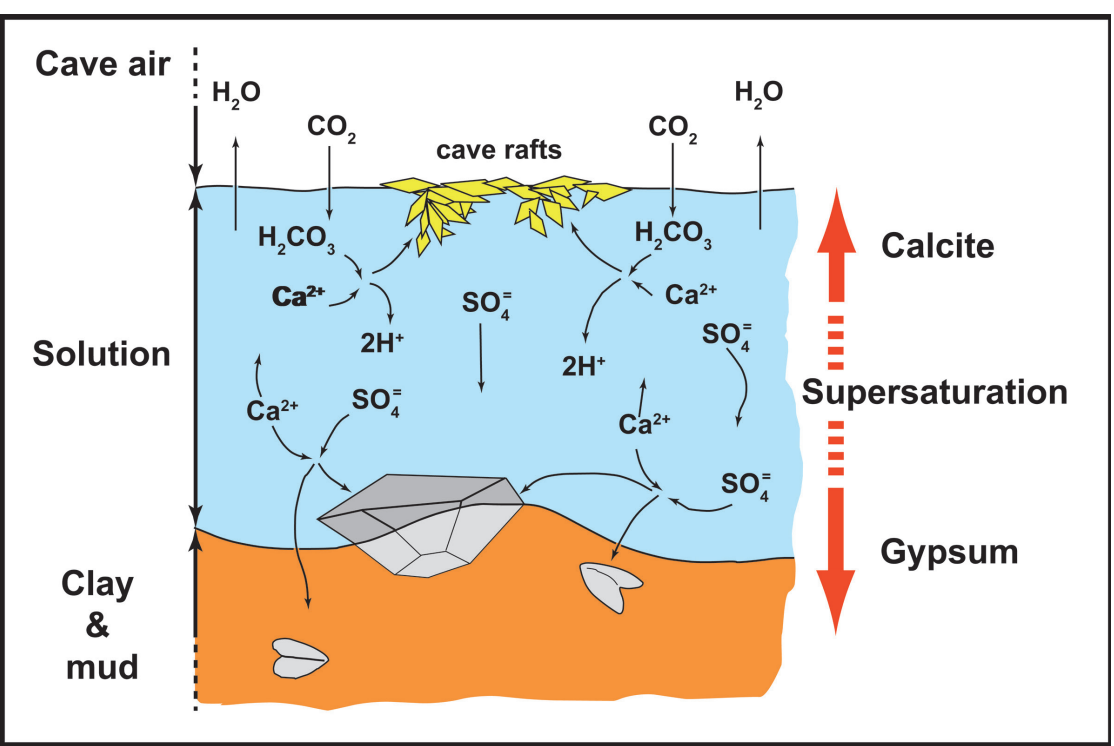

Fig. 10. Carbon dioxide dissolution into the pool water and evaporation causes the development of calcite rafts with minor content of gypsum, whereas on the pool bottom euhedral gypsum crystals develop (after Forti, 2003, modified)

\section{Gypsum speleothems}

Gypsum speleothems are widespread in gypsum caves and they present obvious differences with respect to calcite ones, due to their distinct genetic mechanisms (evaporation instead of incongruent dissolution, $\mathrm{CO}_{2}$ production and/or degassing).

Gypsum stalactites are typically more contorted, botryoidal, and multi-branched. Their growth depends much more, if not exclusively, upon external water film flow rather than the central feeding tube, which often is partially or totally obstructed by gypsum crystals or even completely missing.

Stalactites are found quite commonly in the Italian gypsum caves, but stalagmites are very rare. This is a consequence of the cave climate, humid enough to enhance the development of coralloids driven by capillary uplift and evaporation. In warmer climates (like those of Sorbas, Spain, or New Mexico,
United States) stalagmites are as common as stalactites (Calaforra et al., 1992).

The fact that evaporation is by far the most important genetic mechanism, explains why some types of speleothem common in calcite are very rare in gypsum, or even completely absent. Gypsum never forms cave pearls, while calcite pisoliths are rather common in gypsum caves. Gypsum helictites have been documented in only one cave in Sicily, Italy (Forti, 1987).

In contrast, wind-controlled gypsum speleothems, like rims and trays, may develop much easier in these caves (Chiesi \& Forti, 1992; Calaforra \& Forti, 1994). Wind-deflected gypsum stalactites are bended in the opposite direction with respect to the analogous calcite ones (Forti, 1996).

Table 5. Special gypsum speleothems and their genetic mechanisms.

\begin{tabular}{|c|c|c|}
\hline Name & Genetic mechanism & Reference \\
\hline Christmas tree & Capillary uplift and evaporation along with condensation-corrosion & Calaforra \& Forti, 1994 \\
\hline Gypsum balls & Capillary seepage and evaporation & Calaforra \& Forti, 1993 \\
\hline Hollow stalagmites & Cycles of erosion-dissolution followed by capillary uplift and evaporation & Calaforra \& Forti, 1993 \\
\hline & Segregation by freezing Capillary uplift and sudden & Fedorov, 1883 \\
Gypsum powders & evaporation after a rainstorm & Calaforra \& Forti, 1994 \\
& Guano digestion Hydration & Forti, 1988 \\
Chiesi et al., 1992
\end{tabular}

corresponds to the fir trunk, which seems to be (but in reality is not) linked to the center of the horizontal lower part of the tray. The peculiarity of such assemblages is that the tray and the stalagmite will never touch each other. This is because, while the stalagmite increases its height progressively, the central lower part of the tray gradually dissolves. The space between the tray and the stalagmite is maintained relatively constant by two opposite processes, evaporation and condensation, which control the development and the shape of both speleothems. Capillary uplift and evaporation on top of the stalagmite makes this speleothem grow, but in the meantime the moist air trapped under the tray is forced to condense on the lower part of it. This condensation

\section{Unique gypsum speleothems}

Besides the normal speleothems, gypsum caves host some special ones (Table 5), which up to present, seem to be restricted to a small number of caves. Solution/evaporation processes under special local boundary cave climate conditions control the genesis of all these speleothems.

\section{Christmas tree}

The Rocking Chair Cave (New Mexico; Calaforra \& Forti, 1994) is particularly rich in gypsum trays, the development of which is controlled by strong air currents characterizing some of the cave passages. One of these trays, together with the underlying stalagmite, forms an assemblage resembling a Christmas tree. In fact, the tray has a rather symmetrical conical shape looking like a fir crown whereas the lower stalagmite water is depleted in gypsum and therefore solution causes the evolution of a small dome on the lower part of the tray just over the growing stalagmite. Condensed water, saturated by gypsum from the tray, eventually drips over the stalagmite where the capillary uplift and evaporation makes its top grow upward. The permanent condition of undersaturation at the top of the dome avoids the possibility of the stalagmite's tip to merge with the tray's base.

\section{Gypsum balls}

The gypsum balls are layered, spheroidal gypsum formations (up to $10 \mathrm{~cm}$ in diameter), with an internal structure consisting of radially-elongated crystals. 
Such speleothems have been reported only from caves in the Sorbas area (Calaforra \& Forti, 1993). They develop on vertical and subvertical walls just along subhorizontal clayey-sandy interbeds, and only in the deepest part of the caves where percolation and supersaturation remain constant year around (Fig. 11).

The sub-horizontal disposition of the gypsum layers with thin permeable interbeds favors capillary seepage of slightly supersaturated solution towards preferred points of the cave walls, where evaporation and consequent precipitation can proceed, allowing the evolution of the gypsum balls (Fig. 11 A-C). Normally, these speleothems are compact and consist of lengthened gypsum fibers disposed in a radial structure. As they grow old, gypsum balls may develop an internal drainage tube from the sandy-clayey interbed. Consequently, undersaturated solutions may enter balls and dissolve their lower part causing the partial emptying of these spheres and even their complete destruction (Fig. 11 D-E) (Calaforra, 1998).

\section{Hollow gypsum stalagmites}

Hollow stalagmites have been firstly described from Covadura Cave, Spain (Calaforra \& Forti, 1993), but earlier observed in Jansill Cave, New Mexico, USA (Peerman \& Belski, 1991). These are very narrow (no more than $4-5 \mathrm{~cm}$ in diameter) and tall (up to $150 \mathrm{~cm})$ stalagmites with an internal tube $(2-3 \mathrm{~cm}$ in diameter), which often reaches the bottom of the speleothem. Their external surface consists of several equidimensional upside-down conical elongated segments. At both occurrences these speleothems develop very close to the external surface, from which fresh water seepage percolates very rapidly. The climate of both areas (hot and dry with rare rainstorms) is fundamental for the developing of such hollow stalagmites. During the short intense wet periods, infiltration water, undersaturated with respect to gypsum, drips on top of the stalagmites producing the central tube. During the dry periods (practically most of the year), the water trapped inside the tube is driven by capillary forces to the top of the stalagmite where it evaporates thus inducing the growth of a new portion, the top of which is larger than the bottom due to the evaporative processes. Several subsequent wet and dry periods are responsible for the final shape of the hollow stalagmites.

\section{Gypsum powders}

Cave powder is a rather common soft deposit, which may be found in any type of cave. It is composed of very small crystal grains (10 to $50 \mu \mathrm{m})$ of different mineralogy (Hill \& Forti, 1997). The first gypsum cave powders were described from Kungur Ice Cave (Fedorof, 1883).

Such powders have been observed in different gypsum cave environments under various climates, and although their morphology is practically the same, they differ from a genetic point of view.

Presently four different mechanisms for the origin of gypsum powders are known: 1) fast evaporation, 2) freezing, 3) biogenic reactions within guano, and 4) hydration.

\section{Gypsum powder induced by fast evaporation}

In caves developed in hot and dry areas, like those of New Mexico (Park's Ranch Cave; Calaforra \& Forti, 1994), characterized by brief but strong rainstorms,

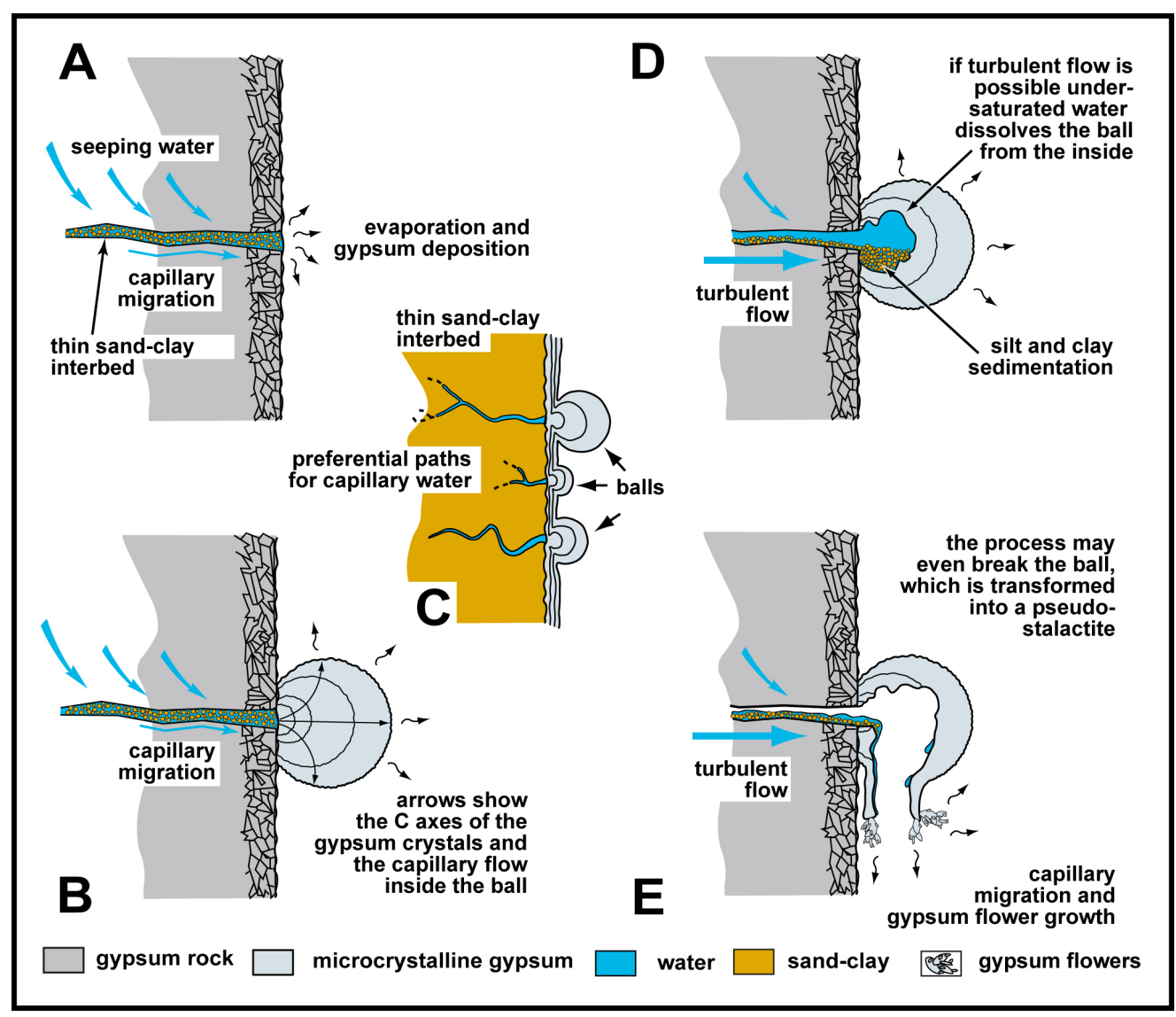

Fig. 11. Genetic process and evolution of gypsum balls (after Calaforra \& Forti, 1993, modified). 
gypsum powder covers the cave walls only between these rare events. Its development is controlled by the capillary uplift and sudden evaporation of the water, which is pushed into the porous microcrystalline structure of the cave walls by the hydrostatic pressure caused by the flood following the rainstorm. This gypsum powder remains unaltered until a new flood washes it away and starts a new cycle of powder formation.

In a different climate regime, near Neuquen (Argentina) (11 in Fig. 1), special speleothems develop from gypsum powder within Cueva del Leon (Lion Cave); the gypsum dust flowstones (Forti et al., 1993).

They consist of several layers (1-2 mm thick) of partially cemented powders (Fig. 12), which evidently were only partially washed away during wet periods. Their evolution starts during a dry period (Fig. 12A) when gypsum dust forms practically following the same mechanism described in the New Mexico caves.

During wet periods, which are extremely shorter compare to the dry ones, no floods occur, but evaporation cannot balance dripping and/or seepage. Consequently a small flow is active over the floor deposits (Fig. 12B). These waters partly dissolve and erode the still unconsolidated gypsum powders but also play a role in diagenesis via evaporation and transformation of the powders into a partially cemented deposit at the beginning of a new dry period (Fig. 12C).

\section{Gypsum powder induced by freezing}

This is by far the first described type of gypsum powder, known since the last part of the $19^{\text {th }}$ century (Fedorof, 1883). Ephemeral gypsum powder is relatively common over subhorizontal, less inclined, surfaces of ice speleothems in caves experiencing seasonal freezing. In particular, this type of powder has been documented from Kungur Ice Cave (5 in Fig. 1, Fedorof, 1883) and Pinega Cave (4 in Fig. 1, Korshunov \& Shavrina, 1998).

In Kungur and Pinega gypsum caves, powders consisting of very small euhedral gypsum crystals

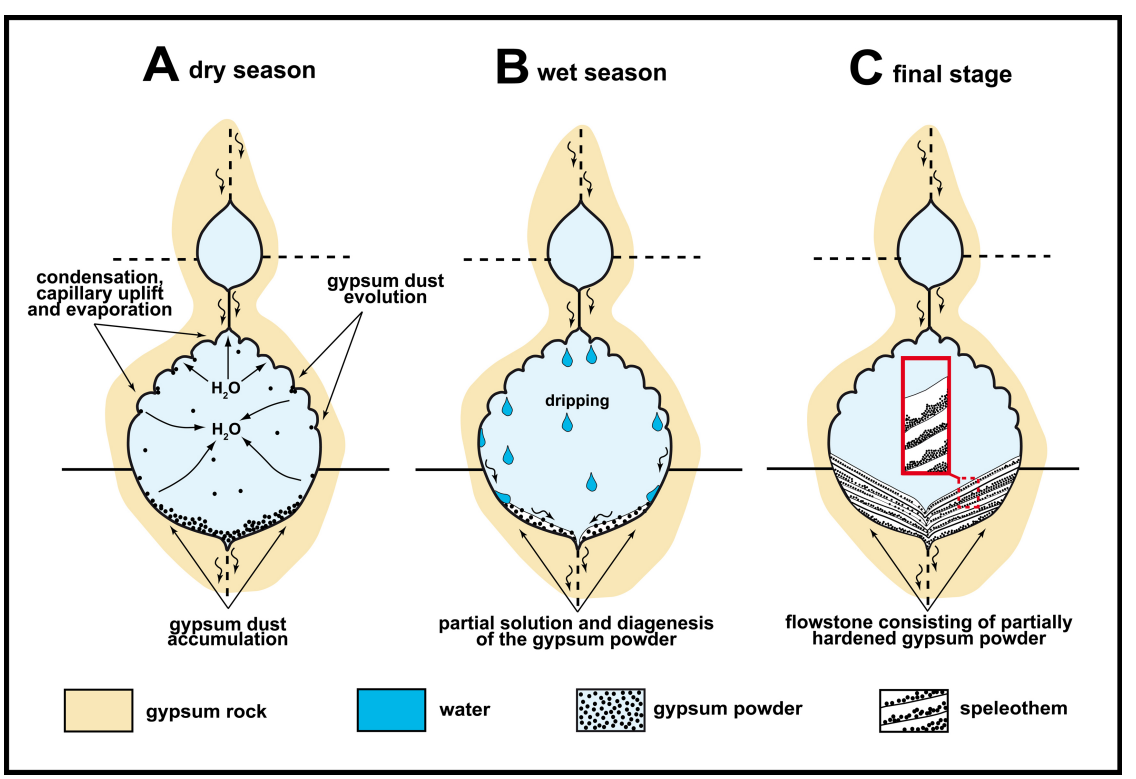

Fig. 12. Evolution of a partially hardened flowstone in an area characterized by a dry and humid season (after Forti et al., 1993, modified). accumulate right over the ice surface. The crystallization process is caused by fractional freezing and produces widespread deposits up to several $\mathrm{cm}$ in thickness. During the following spring, the melting ice water totally dissolves these ephemeral deposits, thus the cryogenic gypsum powders last only few months every year.

\section{Gypsum powder induced by guano digestion}

It is well-known that the complex biologic reactions occurring within guano are responsible for the precipitation of different minerals (Hill \& Forti, 1997). It was observed that when guano deposits are within a gypsum cave in a temperate environment, like that of Santa Ninfa Cave (Sicily, Italy) (3 in Fig. 1), the per ascensum capillary migration of gypsum-saturated solution inside fresh guano, combined with its biogenic oxidation, causes the development of a pale yellow powder of pure gypsum on top of the guano deposit (Forti, 1988).

\section{Gypsum powder induced by hydration}

In extremely dry and hot climates (e.g., in gypsum caves of Punta Alegre diapir in Cuba; or in halite caves from Atacama Desert) gypsum easily transforms into bassanite (Chiesi et al., 1992; De Waele et al., 2016). This process is restricted to the first meters close to wide entrances, where the sun radiation directly reaches the gypsum wall. The newly formed bassanite consists of very small isolated grains that cover the unweathered gypsum rock. During the wet season, rainstorms noticeably increase the cave humidity so that the bassanite grains absorb water from the moist air and rehydrate, thus forming a thin layer of gypsum powder. Gypsum is more stable than bassanite and therefore it may survive subsequent rainstorms forming permanent deposits of gypsum powder.

\section{Gypsum crystals}

Gypsum crystals from few to tens of centimeters in length are without doubt the most common secondary deposits found in evaporite caves at all latitudes and in all climate zones of the world. They are commonly found as free deposits, though more frequently they form druses anchored to the cave walls.

The largest of these crystals (lenticular euhedral crystals, often showing swallow tail or arrowhead twins) may sometimes reach the length of 1-2 $\mathrm{m}$ and they form typically within interbedded clayeysandy layers in areas with a temperate humid climate (like Italy, Spain, and Ukraine), where their development is driven by the slow flow of capillary waters, the evaporation of which causes a very low supersaturation.

In fact it has been proved that the shape of a gypsum crystal (lenticular or prismatic) and the development of single and/or twin or splitted crystals is controlled only by the energy of crystallization, which in turn is function 
of the supersaturation of the feeding solution (Russo, 1981) (Fig. 13A). When supersaturation is extremely low, tabular epitaxial crystals develop (Fig. 13B), but if slightly increases, lenticular shaped, often twinned, crystals are formed (Fig. 13C); finally, at higher supersaturation only prismatic crystals develop (Fig. 13D).

It is not the purpose of this paper to describe or even summarize all different varieties, types, and forms of gypsum crystals, since they exhibit an enormous variation with respect to their shape, dimension, and purity. Also, the genetic mechanisms leading to their development can vary significantly, even though by far the most common origin is supersaturation induced by evaporation. Detailed discussions of these aspects can be found in specific papers by Casali \& Forti (1969), Hill \& Forti (1997), and Forti (1986, 1988).

Gypsum "flowers" (aggregates of lenticular gypsum crystals) (Fig. 13C), which represent the analogues of calcite/aragonite coralloids in the carbonate caves, are ubiquitous. Their development is quite fast and their genesis is due to the evaporation of a thin water film slowly driven by capillary forces over protruding points of the cave walls. Gypsum flowers are highly sensitive to air currents and therefore, in gypsum caves it is common to see these formations with gypsum macrocrystals elongated towards the prevailing wind direction. A classic example comes from the karst area of Neuquen (Argentina), where totally wind-controlled flowers develop inside "gypsum chimneys", that are characterized by strong permanent hot and humid air currents moving upward (Forti et al., 1993).

Another rather unusual type of gypsum flowers, though more common in caves from humid temperate or tropical climate, is that developing over active calcite speleothems fed by the same solution (Forti \& Marsigli, 1978). Gypsum flowers develop even when feeding water is depleted in $\mathrm{Ca}^{2+}$ due to the simultaneous deposition of calcite, which prevents the solution to become oversaturated with respect to gypsum. The explanation of this phenomenon (illustrated in Fig. 13C) is given by the contrasting chemical content of the waters feeding the calcite speleothems and gypsum flowers, respectively. In fact, the first one flows rapidly, but a minimal fraction of it is driven by the capillary forces over protruding points where it evaporates, thus becoming supersaturated with respect to gypsum. Starting from the existence of the gypsum flowers over active carbonate formations and taking into account their different genetic mechanisms (incongruent dissolution and evaporation) it has been possible to prove that the
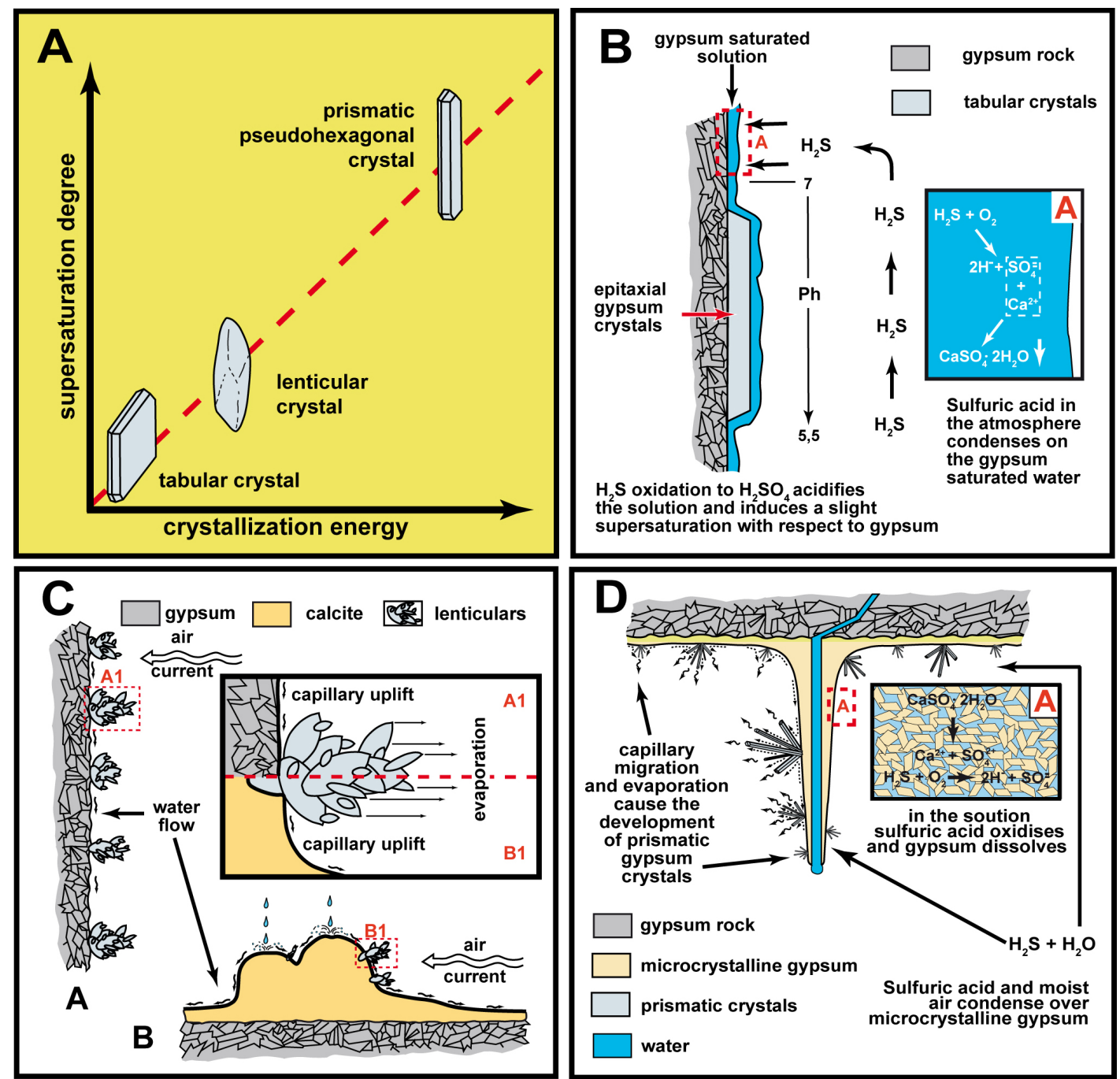

Fig. 13. A) Crystallization energies and corresponding gypsum crystal shapes; B) Mechanism allowing tabular crystal development in Santa Ninfa Cave (after Forti, 1988, modified); C) Mechanisms by which gypsum roses grow over gypsum walls and calcite speleothems (modified after Forti \& Rabbi, 1981); D) Genesis of gypsum prismatic crystals over gypsum stalactites in Buless and Befana caves (after Forti \& Lucci, 2016, modified). 
relative abundance of one of these minerals over the other in a given gypsum karst is a very good proxy for climate and/or paleoclimate (Calaforra \& Forti, 1999; Calaforra et al., 2008).

\section{Special gypsum crystals}

Among the great variety of gypsum crystals, a number of few unique ones (from the genetic point of view) occur in gypsum caves (Table 6).

Table 6. Special gypsum crystals and their genetic mechanism.

\begin{tabular}{|l|c|l|}
\hline \multicolumn{1}{|c|}{ Crystal type } & Genetic mechanism \\
\hline Cryogenic crystals & Cycles of segregation due to seasonal freezing & Korshunov \& Shavrina, 1998 \\
\hline Tabular epitaxial crystals & Oxidation of $\mathrm{H}_{2} \mathrm{~S}$ in gypsum-saturated water & Forti, 1988 \\
\hline $\begin{array}{l}\text { Microcrystalline aggregates along main } \\
\text { exfoliation planes }\end{array}$ & $\begin{array}{c}\text { Enhanced condensation within narrow widenings, } \\
\text { capillary uplift and evaporation }\end{array}$ & Badino et al., 2011 \\
\hline Prismatic crystals over gypsum stalactites & Oxidation of $\mathrm{H}_{2} \mathrm{~S}$ where no buffering is possible & Forti \& Lucci, 2016 \\
\hline
\end{tabular}

\section{Cryogenic crystals}

In some gypsum caves of Pinega (northern Russia, 4 in Fig. 1) where winter freezing affects the relatively thick clay deposits, strange aggregates, named gypsum yozh (hedge-hog like speleothems) are formed (Malkov \& Shavrina, 1991; Korshunov \& Shavrina, 1998). They are rounded (if they grow deep inside a thick clay deposit), hemispherical (if the clay deposit is in contact with the walls or the ceiling of the cave), or even planar masses (if the clay layer is relatively thin). Their diameter ranges from a few $\mathrm{cm}$ up to $30 \mathrm{~cm}$ and their surface consists of fans made by lens-shaped splitted gypsum crystals; the degree of splitting is controlled by the supersaturation state of the solution (Russo, 1981). Their color ranges from white to brown depending on the amount of clay inclusions, which is inversely proportional to how rapidly freezing proceeds, as testified by the fact that the purest samples have always been observed in places far from the cave entrance(s), where the change in temperature is more gradual. Finally, the rounded yozhs almost always have a little cavity inside (from a few to $15 \mathrm{~mm}$ in diameter), often hosting a small stone that rattles when shaken (Korshunov \& Shavrina, 1998).

The genesis of this speleothem occurs only in areas of seasonal freezing and is controlled by the progressive freezing of the water trapped within the clay sediment. Growth appears to begin around a little cavity inside the clay (Fig. 14), which is filled by water during summertime. The genesis of this cavity is normally controlled by the presence of a pebble that enhances the deposition of ice just around it (Fig. 14A). Cycles of freezing and melting progressively increase the volume of the cavity around the pebble until it becomes large enough to allow the evolution of a gypsum yozh.

At the beginning, the preferential direction of growth is opposite to the front of freezing, just following the supersaturation gradient thus creating a subspherical structure (Fig. 14B). The thin layer of gypsum deposited during winter does not dissolve in the springtime when the hosting clay is newly refilled by water; this is because at the beginning of spring water remains saturated with respect to gypsum for 1-2 weeks (Fig. 14C). The internal cavity rests open (no gypsum precipitation) because the crystals prefer to grow towards the positive temperature gradient (i.e., along the gypsum/clay interface). Also, during freezing periods its water partially migrates through capillary forces to the gypsum/clay interface. It is evident that each freezing period may only induce the development of one very thin layer of gypsum; therefore, thousands of freezing-melting cycles are required to develop the largest yozhs (Fig. 14D). A rough calculation estimated that the largest yozhs developed over the last 8000 years (Korshunov \& Shavrina, 1998).

Another type of yozh, smaller than the previous one has been documented only from Ledyanaya Volna Cave (Pinega, Russia). It developed inside the body of a huge mass of ice (a small underground glacier) and it consists of a sub-spherical (6-8 $\mathrm{cm}$ in diameter) porous radial aggregate of needle-like gypsum crystals (1-3 $\mathrm{mm}$ wide and $1-4 \mathrm{~cm}$ long) without internal cavity. Korshunov and Shavrina (1998) argued that it formed due to diagenetic processes (secondary recrystallization). During melting periods this process transform gypsum moonmilk or gypsum powder trapped inside the ice into a rounded aggregate of centimeter-sized gypsum crystals.

\section{Tabular epitaxial crystals}

Deep inside Santa Ninfa Cave (Sicily, Italy) on a subvertical gypsum wall above a river with $\mathrm{H}_{2} \mathrm{~S}$ rich waters, a strange transparent flat surface consisting of epitaxial tabular gypsum crystals is actively developing. A perennial laminar gypsum-saturated water film flows over this gypsum wall, but evaporation is not possible due to the fact that the relative humidity is constantly near $100 \%$. The evolution of the epitaxial tabular crystal (Fig. 13B) is caused by the very low supersaturation induced by the hydrolysis of $\mathrm{H}_{2} \mathrm{~S}$ from the cave atmosphere with the water flowing over the cave wall (Forti \& Lombardo, 1998). The sulfide ions are then oxidized to sulfate, but the achieved slight supersaturation is insufficient to allow the deposition of new crystals (which requires the development of a new three dimensional structure), therefore only an epitaxial overgrowth (allowing for the evolution of a two dimensional structure) can occur (Russo, 1981). Up to present such epitaxial gypsum crystals have been observed only in Santa Ninfa Cave.

\section{Microcrystalline aggregates along main exfoliation planes}

In many of the occurrences with giant gypsum crystals exposed on the cave walls, there are white, secondary microcrystalline aggregates developed just along the widened main exfoliation planes (010). They form because during wet periods condensation occurs more easily inside these planes than over the 

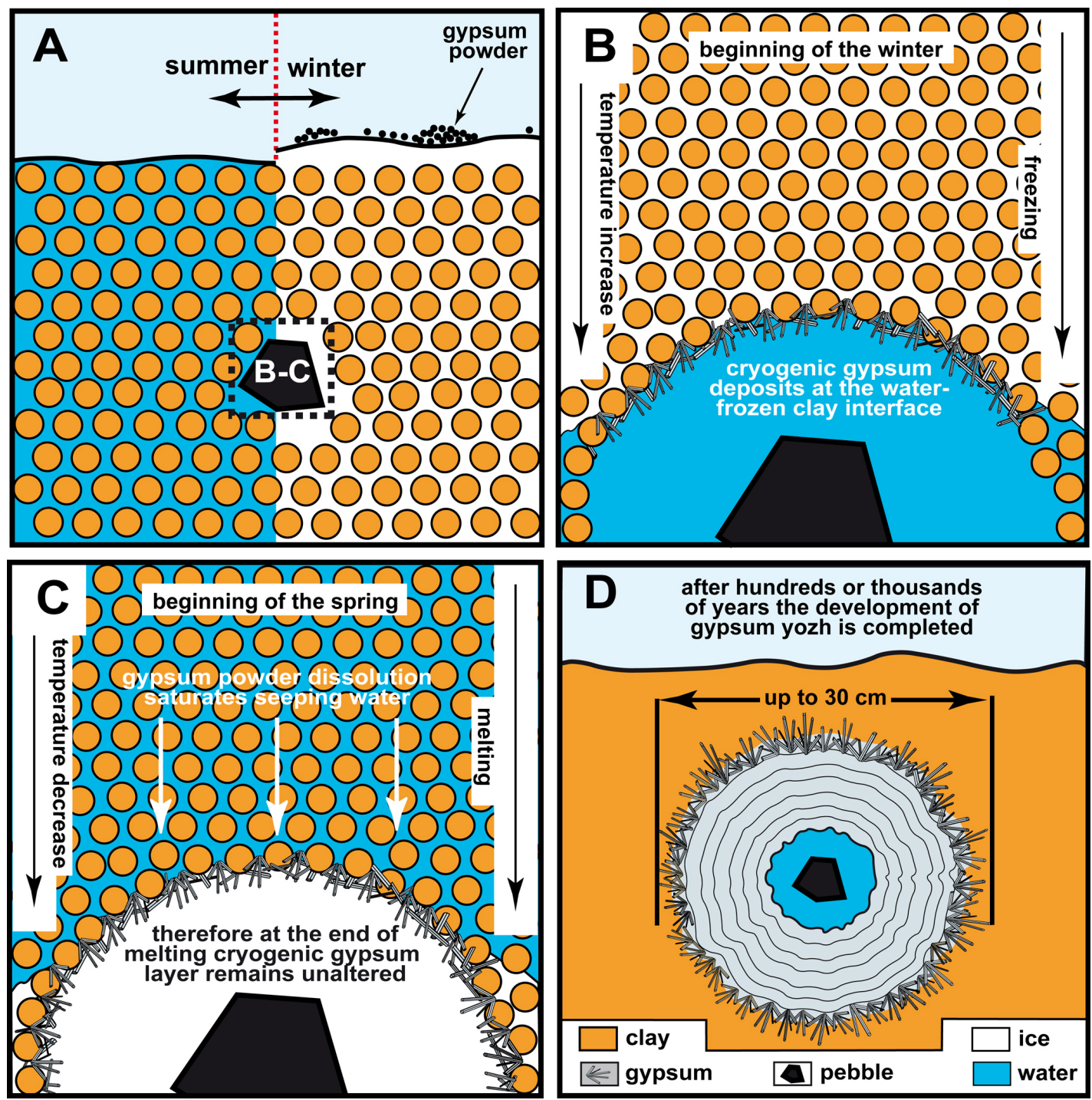

Fig. 14. Genesis and evolution of a gypsum yozh within the seasonally frozen clay of Pinega karst.

flat external crystal surfaces (Badino et al., 2011). Moreover, capillary forces drive the condensed water from the external surfaces inside these widened planes, where they become saturated with respect to gypsum. When the relative humidity of the cave atmosphere lowers, evaporation resumes causing the capillary movements within these exfoliation planes to reverse. Evaporation triggers the deposition of gypsum microcrystals only at the tip of the exfoliation planes with the development of straight elongate partially rounded aggregates (Fig. 15).

\section{Prismatic crystals over gypsum stalactites}

As already mentioned, the growth of gypsum flowers over both gypsum walls and calcite flowstones is rather common in many caves of temperate areas. However, until recently, no euhedral crystals were reported growing over gypsum stalactites. Recently, elongated pseudo-hexagonal crystals (up to few $\mathrm{cm}$ in length) have been observed covering active stalactites in two caves of Emilia-Romagna (Italy), Befana and Buless, respectively (Ronda Speleologica Imolese, 2011; Forti \& Lucci, 2016) (Fig. 13D).

Due to the fact that prismatic crystals require much more crystallization energy than the lenticular ones (Russo, 1981), it is evident that the genetic mechanism for the development of these crystals must differ from that of the normal gypsum roses (Fig. 13D). Both these caves host sulfide flowing waters, but the gypsum stalactites are fed only after rain events, because the caves are very close to the surface. The combination of these two factors controls the development of prismatic crystals. In fact, during dry periods the condensation of $\mathrm{H}_{2} \mathrm{~S}$ over the gypsum stalactites and its oxidation to sulfuric acid occurs with no dilution by meteoric seeping waters. Therefore, evaporation increases its concentration and thus, high supersaturation is achieved, which in turn causes the precipitation of prismatic crystals instead of "normal" lenticular ones.

\section{Cave minerals}

Gypsum caves host 27 minerals (Table 7); four of them (buserite, chloromagnesite, gaylussite, and howlite) are novel for the cavern environment (Hill $\&$ Forti, 1997) and restricted to a single cave each. Obviously, gypsum and calcite are by far the most common chemical deposits and they are present in almost all studied caves, however, until present, eight different mineralogical groups have been observed in gypsum karst.

The group of oxides and hydroxides is the largest with 7 minerals (asbolane, birnessite, buserite, goethite, hematite, ice, and lepidocrocite) followed by five sulfates (bassanite, celestite, epsomite, 

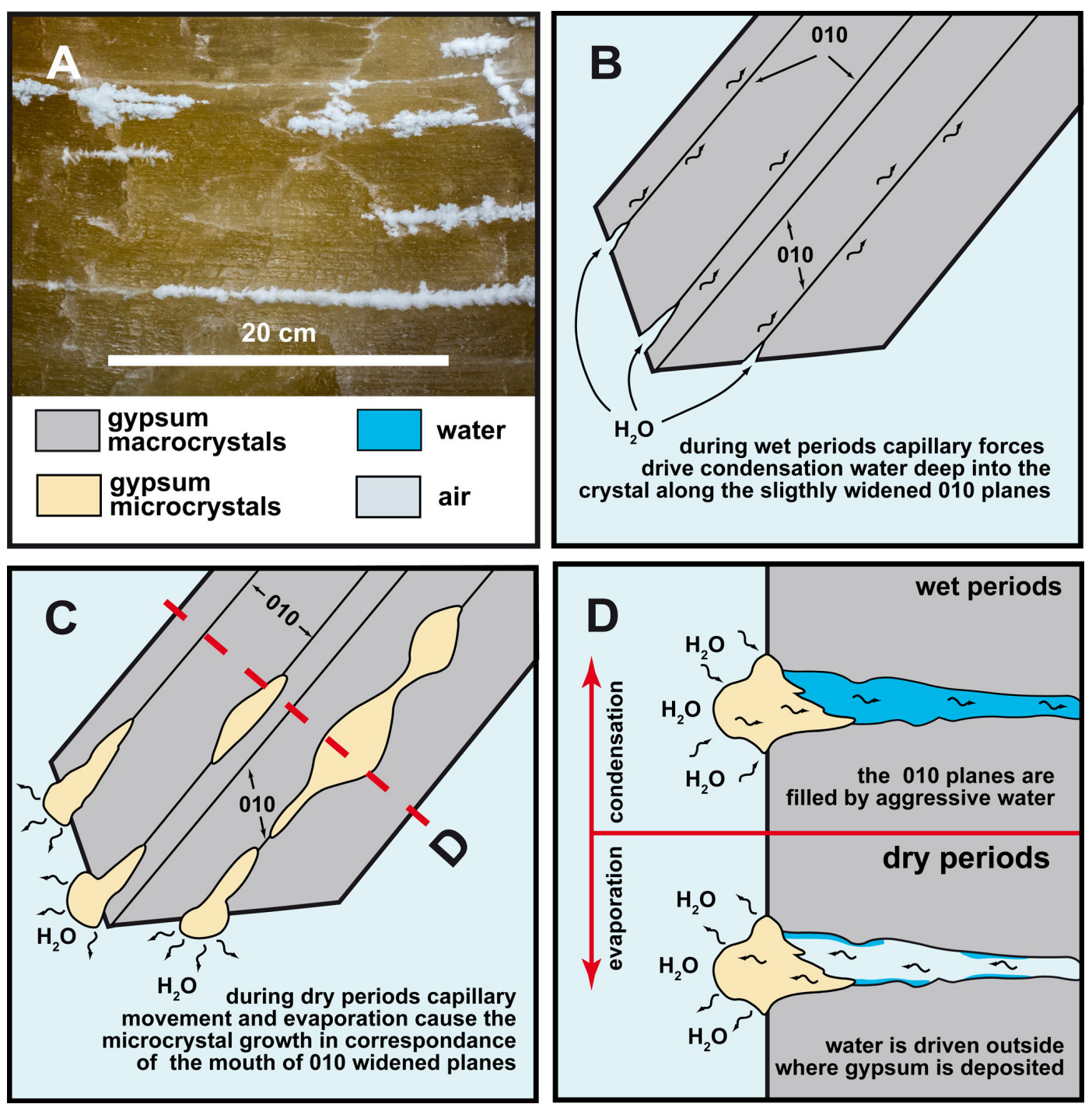

Fig. 15. Genesis and evolution of microcrystalline aggregates along the slightly widened 010 exfoliation planes (modified after Badino et al., 2011). A) white microcrystalline aggregates over a large gypsum crystal (Photo by Piero Lucci); B-C-D) water movements driven by condensation-evaporation processes and the consequent evolution of microcrystalline aggregates.

gypsum, and mirabilite) and four carbonates (calcite, dolomite, gaylussite, and rhodochrosite). The halides (chloromagnesite, halite, and sylvite), phosphates (brushite, fluorapatite, and hydroxylapatite), and silicates (chalcedony, opal, and quartz) are represented by 3 minerals each, whereas only one borate (howlite), and one native element (sulfur) are present.

Among the oxides, ice forms huge perennial and/ or ephemeral deposits in the caves of Pinega and Kungur (Russia). Practically, apart from cave pearls, ice can take the form of any of the other speleothem types. Worth mentioning, however, are the largest sublimation ice crystals from Kungur and Ordinskaya caves, which are probably among the best examples in the world.

Iron and manganese amorphous oxides/hydroxides are common in gypsum caves where their normal occurrence is as thin crusts. The best examples of such deposits come from the following caves: 1) Novella (Bologna, Italy), 2) Pelagalli (Bologna), and 3) Zoloushka (Ukraine).

In Novella Cave, the Fe oxides-hydroxides are present along with Mn oxides as thin black layers within huge calcite speleothems. The genesis of these deposits is apparently related to the occurrence of periodic fires (in the last few centuries) that burned the bushes above and around the cave (Forti \& Querzè, 1978). In fact, the destruction of the bushes causes the alteration of the soil composition with a sudden stop in the development of calcite speleothems. Simultaneously the $\mathrm{Fe}$ - and $\mathrm{Mn}$-rich bush ashes react with rainwater within the organic rich soil, the oxidation of which induces the reduction of $\mathrm{Fe}$ and $\mathrm{Mn}$ to bivalent ions. When seepage reaches the underground voids $\mathrm{Fe}^{2+}$ and $\mathrm{Mn}^{2+}$ ions are immediately oxidized thus forming the thin black layers. The deposition of the oxides lasts only a very short time lapse, because the development of new bushes allows to re-establish the environmental conditions for the development of calcite flowstones via incongruent dissolution of gypsum.

In Pelagalli Cave red stalactites, stalagmites, and flowstones show largely prevailing layers of $\mathrm{Fe}$ and Mn oxides/hydroxides that alternate with thin layers of gypsum and opal. This is the only place where three well-defined iron minerals were identified: goethite, hematite, and lepidocrocite. The evolution of these speleothems was controlled by very uncommon environmental parameters: 1) presence at the surface of a small swamp with strongly reducing conditions where large quantities of iron and manganese were 
Table 7. List of minerals precipitated in gypsum caves: ${ }^{*}=$ new for the cavern environment and until present exclusive to gypsum caves).

\begin{tabular}{|c|c|c|c|c|}
\hline & Name & Chemical formula & Occurrence & First Reference \\
\hline 1 & Asbolane & $\begin{array}{c}\mathrm{Mn}^{4+}(\mathrm{O}, \mathrm{OH})_{2} \cdot(\mathrm{Co}, \mathrm{Ni}, \mathrm{Mg}, \mathrm{Ca}) \\
\times(\mathrm{OH})_{2 \times} \cdot \mathrm{nH}_{2} \mathrm{O}\end{array}$ & Mingled with birnessite, in a red-brown stalactite & Volkov et al., 1987 \\
\hline 2 & Bassanite & $\mathrm{CaSO}_{4} \cdot 0.5 \mathrm{H}_{2} \mathrm{O}$ & White powder on gypsum & Chiesi et al., 1992 \\
\hline 3 & Birnessite & $(\mathrm{Na}, \mathrm{Ca}, \mathrm{K})_{0.6}\left(\mathrm{Mn}^{4+}, \mathrm{Mn}^{3+}\right)_{2} \mathrm{O}_{4} \cdot 1.5 \mathrm{H}_{2} \mathrm{O}$ & Mingled with asbolane in a red-brown stalactite & Volkov et al., 1986 \\
\hline 4 & Brushite & $\mathrm{Ca}\left(\mathrm{PO}_{3} \mathrm{OH}\right) \cdot 2 \mathrm{H}_{2} \mathrm{O}$ & Yellow powder over bat guano & Forti, 1983 \\
\hline 5 & Buserite* $^{*}$ & $\mathrm{Na}_{4} \mathrm{Mn}_{14} \mathrm{O}_{27} \cdot 21 \mathrm{H}_{2} \mathrm{O}$ (?) & Mingled with birnessite on muddy lake deposit & $\begin{array}{l}\text { Andrejchouk \& } \\
\text { Klimchouk } 2010\end{array}$ \\
\hline 6 & Calcite & $\mathrm{CaCO}_{3}$ & $\begin{array}{l}\text { All common speleothems } \\
\text { Bladed flowstones } \\
\text { Half-bubbles } \\
\text { Bubbles, rafts } \\
\text { Biogenic flowstone }\end{array}$ & $\begin{array}{c}\text { Forti, } 1996 \\
\text { Forti \& Rabbi, } 1981 \\
\text { Forti \& Chiesi, } 1995 \\
\text { Ercolani et al., } 2013 \\
\text { Forti, } 2003 \\
\text { Poluzzi \& Minguzzi, } 1998\end{array}$ \\
\hline 7 & Celestite & $\mathrm{SrSO}_{4}$ & $\begin{array}{l}\text { Mingled with high Mg-calcite, dolomite, } \\
\text { gaylussite, and halite within cryogenic gypsum/ } \\
\text { calcite crusts } \\
\text { Small crystals at the mouth of a sulfide spring }\end{array}$ & $\begin{array}{l}\text { Tchaikovskiy et al., } 2015 \\
\text { Carrozzini et al., } 1996\end{array}$ \\
\hline 8 & Chalcedony & $\mathrm{SiO}_{2}$ & $\begin{array}{l}\text { Associated with calcite in the crust covering } \\
\text { rounded aggregates of howlite }\end{array}$ & Potapov \& Parshina, 2010 \\
\hline 9 & Chloromagnesite $^{*}$ & $\mathrm{MgCl}_{2}$ & Dispersed within epsomite fibers & Cervellati et al., 1975 \\
\hline 10 & Dolomite & $\mathrm{CaMg}\left(\mathrm{CO}_{3}\right)_{2}$ & $\begin{array}{c}\text { Moonmilk mingled with magnesian-calcite, } \\
\text { celestite, gaylussite, and halite within cryogenic } \\
\text { crust of gypsum/calcite }\end{array}$ & $\begin{array}{l}\text { Forti et al., } 2004 \\
\text { Tchaikovskiy et al., } 2015\end{array}$ \\
\hline 11 & Epsomite & $\mathrm{MgSO}_{4} \cdot 7 \mathrm{H}_{2} \mathrm{O}$ & Acicular crystals over mud & Cervellati et al., 1975 \\
\hline 12 & Fluorapatite & $\mathrm{Ca}_{5}\left(\mathrm{PO}_{4}\right)_{3} \mathrm{~F}$ & $\begin{array}{c}\text { With carbonatoapatite in shining gold crusts } \\
\text { over fossil remains }\end{array}$ & Chiesi \& Forti, 1992 \\
\hline 13 & Gaylussite* & $\mathrm{Na}_{2} \mathrm{Ca}\left(\mathrm{CO}_{3}\right)_{2} \cdot 5 \mathrm{H}_{2} \mathrm{O}$ & $\begin{array}{l}\text { Mingled with high-Mg calcite, celestite, dolomite } \\
\text { and halite within cryogenic crust of gypsum/ } \\
\text { calcite }\end{array}$ & Tchaikovskiy et al., 2015 \\
\hline 14 & Goethite & $\mathrm{FeO}(\mathrm{OH})$ & $\begin{array}{l}\text { Large crusts, stalactites and stalagmites with } \\
\text { lepidocrocite, limonite, and } \mathrm{Fe} \text { and Mn oxides }\end{array}$ & Forti \& Rossi, 1989 \\
\hline 15 & Gypsum & $\mathrm{CaSO}_{4} \cdot 2 \mathrm{H}_{2} \mathrm{O}$ & $\begin{array}{c}\text { Many common speleothems and a few peculiar } \\
\text { ones: balls, helictites, hollow stalagmites, } \\
\text { powder, euhedral crystals, yozh }\end{array}$ & $\begin{array}{l}\text { Hill \& Forti, } 1997 \text { and } \\
\text { references therein }\end{array}$ \\
\hline 16 & Halite & $\mathrm{NaCl}$ & $\begin{array}{c}\text { Mingled with Magnesian-calcite, celestite, } \\
\text { dolomite and gaylussite within cryogenic crust of } \\
\text { gypsum/calcite }\end{array}$ & Tchaikovskiy et al., 2015 \\
\hline 17 & Hematite & $\mathrm{Fe}_{2} \mathrm{O}_{3}$ & $\begin{array}{c}\text { Small crystals inside large crusts, stalactites and } \\
\text { stalagmites with goethite, lepidocrocite limonite } \\
\text { and } \mathrm{Fe} / \mathrm{Mn} \text { oxides }\end{array}$ & Forti \& Rossi, 1989 \\
\hline 18 & Howlite* & $\mathrm{Ca}_{2} \mathrm{SiB}_{5} \mathrm{O}_{9}(\mathrm{OH})_{5}$ & $\begin{array}{c}\text { Rounded aggregates covered by a crust of calcite } \\
\text { and chalcedony }\end{array}$ & Potapov \& Parshina, 2010 \\
\hline 19 & Hydroxylapatite & $\mathrm{Ca}_{5}\left(\mathrm{PO}_{4}\right)_{3} \mathrm{OH}$ & $\begin{array}{l}\text { With fluorapatite in shining gold crusts over } \\
\text { fossil remains }\end{array}$ & Chiesi \& Forti, 1992 \\
\hline 20 & Ice & $\mathrm{H}_{2} \mathrm{O}$ & Speleothems, crystals & $\begin{array}{l}\text { Hill } \& \text { Forti, } 1997 \text { and } \\
\text { references therein }\end{array}$ \\
\hline 21 & Lepidocrocite & $\mathrm{Fe}^{3+} \mathrm{O}(\mathrm{OH})$ & $\begin{array}{l}\text { Minor component of stalactites and stalagmites } \\
\text { with goethite, limonite, gypsum and opal }\end{array}$ & Forti \& Rossi, 1989 \\
\hline 22 & Mirabilite & $\mathrm{Na}_{2} \mathrm{SO}_{4} \cdot 10 \mathrm{H}_{2} \mathrm{O}$ & Stalactites, euhedral crystals & Bertolani \& Rossi, 1972 \\
\hline 23 & Opal & $\mathrm{SiO}_{2} \cdot \mathrm{nH}_{2} \mathrm{O}$ & Thin crusts and coralloids & Forti \& Rossi, 1989 \\
\hline 24 & Quartz & $\mathrm{SiO}_{2}$ & Skeleton euhedral crystals over corroded gypsum & Forti, 1993 \\
\hline 25 & Rhodochrosite & $\mathrm{MnCO}_{3}$ & Thin crusts over calcite speleothems & Turchinov, 1993 \\
\hline 26 & Sulfur & $\mathrm{s}$ & $\begin{array}{c}\text { Polymineral flowstones with opal, and } \mathrm{Al} / \mathrm{Fe} \\
\text { oxides. } \\
\text { Small crystals over gypsum stalactites }\end{array}$ & $\begin{array}{l}\text { Carrozzini et al., } 1996 \\
\text { Forti \& Lucci, } 2016\end{array}$ \\
\hline 27 & Sylvite & $\mathrm{KCl}$ & Stalactites & Calandri \& Ramella, 1987 \\
\hline 28 & $\begin{array}{l}\text { Undifferentiated Al- } \\
\text { oxides }\end{array}$ & $\mathrm{Al}_{2} \mathrm{O}_{3}$ & $\begin{array}{c}\text { Polymineral flowstones with opal, sulfur and Fe } \\
\text { oxides }\end{array}$ & Carrozzini et al., 1996 \\
\hline 29 & $\begin{array}{l}\text { Undifferentiated Fe } \\
\text { oxides/ } \\
\text { hydroxides }\end{array}$ & & $\begin{array}{l}\text { Crust with Mn oxides. } \\
\text { Large crusts, stalactites and stalagmites with } \\
\text { goethite, lepidocrocite, limonite and Mn oxides }\end{array}$ & $\begin{array}{l}\text { Turchinov, } 1993 \\
\text { Forti \& Rossi, } 1989\end{array}$ \\
\hline 30 & $\begin{array}{l}\text { Undifferentiated } \\
\text { Manganese oxides/ } \\
\text { hydroxides }\end{array}$ & & $\begin{array}{l}\text { Crust with Fe oxides/hydroxides. } \\
\text { Large crusts, stalactites and stalagmites with } \\
\text { goethite, lepidocrocite and other Fe oxides. } \\
\text { Powder and thick black deposits over mud }\end{array}$ & $\begin{array}{c}\text { Turchinov, } 1993 \\
\text { Forti \& Rossi, } 1989 \\
\\
\text { Andrejchouk \& } \\
\text { Klimchouk, } 2010\end{array}$ \\
\hline
\end{tabular}


solubilized, 2) a subvertical marly-clayey interbed directly linking the swamp to the cave room, allowing a capillary transfer of the reduced ions without possibility to be oxidized, and 3) the dry and relatively warm climate of the cave led to a fast oxidation of $\mathrm{Fe}^{2+}$ and $\mathrm{Mn}^{2+}$, with subsequent deposition of these oxides and hydroxides (Forti \& Rossi, 1989).

Finally, in the hypogenic Zoloushka cave the fast dewatering induced by mining activities caused an extremely fast, biologically driven, oxidation of the solubilized $\mathrm{Fe}^{2+}$ and $\mathrm{Mn}^{2+}$ and the development of many speleothems. The most important are: widespread red stalactites of iron oxides/hydroxides, rare red brown hollow stalagmites of birnessite and some unidentified Fe-Mn oxides (Turchinov, 1993), subaqueous deposits of birnessite and buserite, as well as black powder and thick soft layered deposits of manganese oxides (Andrejchouk \& Klimchouk, 2010).

Amorphous aluminum oxides were observed in the sulfide branch of the Grave Grubbo Cave, where they are deposited along with Fe-Mn oxides, opal, and sulfur in thin flowstones just where sulfide waters emerge from the cave wall. Their genesis was caused by weathering processes of silicate minerals induced by sulfide waters seeping inside in the clay-sand material filling gypsum bedding planes (Carrozzini et al., 1996).

The second largest mineralogical group is composed of carbonates, where, beside calcite, dolomite, gaylussite, and rhodochrosite are also present. Dolomite has been observed as small moonmilk spots over the roof of a short tunnel inside the Spipola Cave (Bologna, Italy; Forti et al., 2004). The necessary magnesium comes from the marly-clayey layers interbedded in gypsum, whereas $\mathrm{CO}_{2}$ diffuses from the cave atmosphere into condensing water. The genesis of dolomite moonmilk was strictly related to a very long dry period that allowed the capillary migration of long-lasting solutions trapped in between the selenite crystals of the cave wall and their total evaporation. These dolomite deposits were completely washed away and/or dissolved when the normal water flow was restored within the cave.

Gaylussite is a new cave mineral that was only observed associated with two other carbonates (calcite, and dolomite), celestite, and halite among the cryogenic polymineral assemblage developing during wintertime inside the Kungur Cave, the only cave in which these deposits have been investigated in detail (Tchaikovskiy et al., 2015). Here, the freezing of large volumes of water causes, at the waterair interface, the development not only of gypsum powders, but also the segregation of thin crusts in which besides primarily gypsum and calcite, the other minerals are also present. The composition of these aggregates seems to be controlled by the specific cave microclimate of the area in which they develop. In the relatively less-cold zones of the cave (> $0^{\circ} \mathrm{C}$ ) progressive deposition induced by freezing and evaporation causes the calcite $\rightarrow$ dolomite segregation sequence, while in the colder areas $\left(-5\right.$ to $\left.-3^{\circ} \mathrm{C}\right)$ the sequence is calcite $\rightarrow$ magnesian calcite $\rightarrow$ gaylussite (Tchaikovskiy et al., 2015).
Finally, rhodochrosite was reported only from the Zoloushka Cave, Ukraine (Turchinov, 1993), where it is present as a thin crust or as a boxwork of microcrystals over a corroded gypsum wall.

Four other sulfates (besides gypsum) are known from gypsum caves: bassanite, celestite, epsomite, and mirabilite. Bassanite was observed as whitish thin layers of powder in the small gypsum caves of the diapir of Punta Alegre, Cuba (Chiesi et al., 1992). Bassanite is the result of partial dehydration of gypsum, possibly due to the hot climate of the area. The fact that this mineral was present only close to the cave entrances, where probably the sun radiation may directly impact gypsum walls, confirms the suggested genetic mechanism. A similar situation was observed in the Atacama caves (De Waele et al., 2017).

There are two cave locations in which celestite is present: Grave Grubbo and Kungur caves. In Grave Grubbo Cave celestite is present as euhedral small crystals growing around a sulfide spring and its genesis is induced by the oxidation of $\mathrm{H}_{2} \mathrm{~S}$ just at the mouth of the spring (Carrozzini et al., 1996). In Kungur Cave the presence of this mineral is ephemeral; it only forms during wintertime within cryogenic polymineral aggregates developing over some of the cave lakes (Tchaikovskiy et al., 2015).

Epsomite and mirabilite are ephemeral minerals forming in several gypsum caves near Bologna (Bertolani \& Rossi, 1972; Cervellati et al., 1975). Epsomite was known as gypsum cave mineral since the antiquity (Laghi, 1806) and, in wintertime is present as very thin (less than $0.1 \mathrm{~mm}$ ) elongated fibers up to 10-15 cm long growing over the exposed surfaces of clay interbeds or thick clay/mud deposits on the cave floor, whereas in the springtime it disappears being dissolved by moist air (Cervellati et al., 1975). The $\mathrm{Mg}$ needed for its deposition comes from the clayeymarly interbeds, which are common in the gypsum outcrops. Mirabilite has been reported from Gortani Cave where it forms small stalactites and/or euhedral crystals (Bertolani \& Rossi, 1972). Mirabilite is a deliquescent compound and therefore its presence in this specific cave is limited to a short, very cold and dry period in the middle of the winter. As for the $\mathrm{Mg}^{2+}$ of epsomite, the $\mathrm{Na}^{+}$ions are derived from the clayeymarly interbeds.

Chlorides, phosphates, and silicates are represented by three minerals each. The three chlorides were observed in three different caves. To date, chloromagnesite is known to occur only in Buco dei Buoi Cave near Bologna (Cervellati et al., 1975), where it is present as small microcrystals. Halite was reported only as a minor component of the polymineral cryogenic crusts of Kungur Cave (Tchaikovskiy et al., 2015). Finally, pure sylvite has been described forming small stalactites within Darhedj Cave (Algeria); this mineral is present in the evaporitic sequence overlying the cave and therefore it is solubilized by seeping water and redeposited by evaporation (Calandri \& Ramella, 1987).

Gypsum caves host only three very common phosphates: brushite, hydroxylapatite, and fluorapatite. The last two were observed as a gold shining thin crust 
over a fossil bone in Milocchite Cave, Sicily (Chiesi \& Forti, 1992), whereas yellowish lenses of brushite were observed inside an old bat guano deposit in the Prete Santo Cave near Bologna (Forti, 1983).

Most of the known cave phosphates (as well as some nitrates, chlorides, and sulfates), directly derive from the internal reaction in the guano deposits (Hill \& Forti, 1997), without any influence from seeping water and/or cave bedrock. Therefore, it is expected that many other phosphates must be present in gypsum caves, where huge guano deposits exists, but they are still waiting to be discovered!

The only known three silicates from gypsum karst are chalcedony, opal, and quartz, and each of them is restricted to a single cave. Chalcedony (microcrystalline quartz) forms, along with calcite the outer shell of the howlite aggregates described from Ordinskaya Cave (Kungur, Russia) by Potapov and Parshina (2010); no genetic mechanism was proposed by the authors. Opal is present with thin botryoidal crusts dispersed within $\mathrm{Fe} / \mathrm{Mn}$ oxideshydroxides forming stalactites, stalagmites,

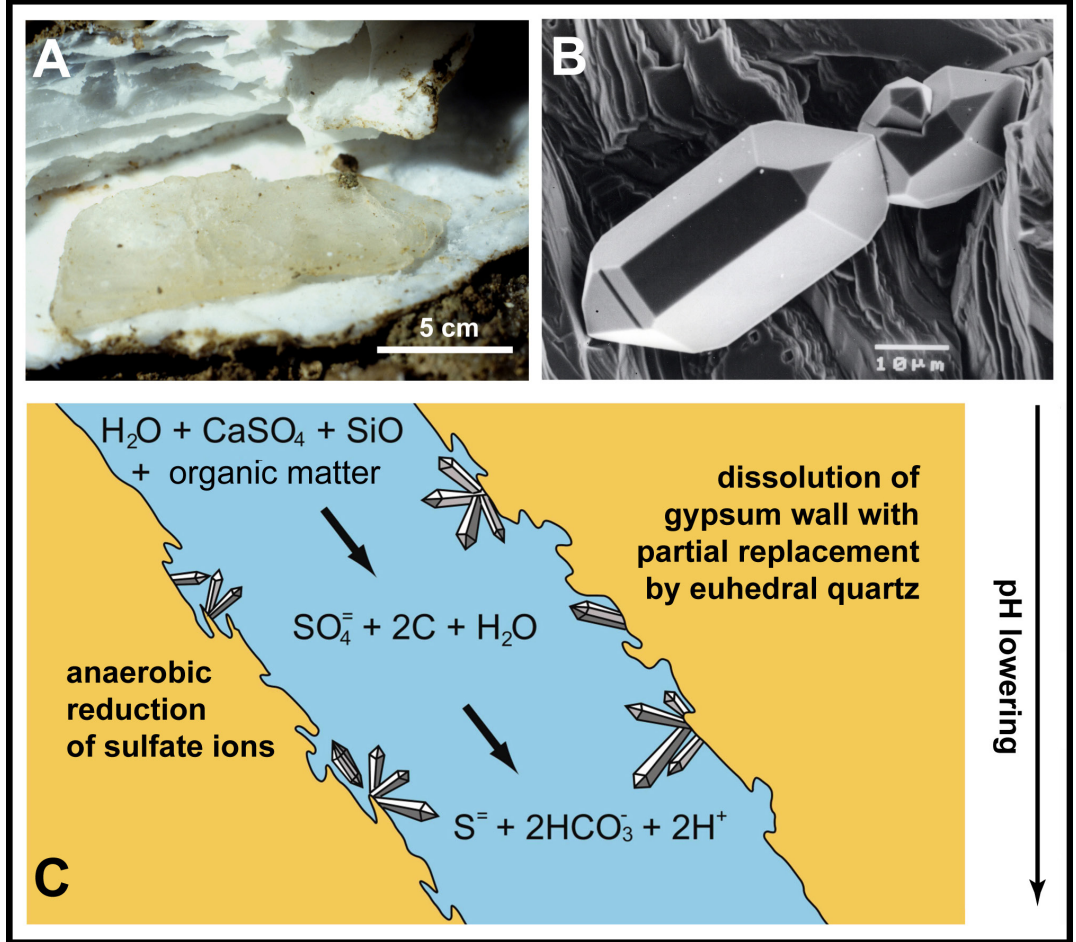

Fig. 16. A) Corroded gypsum crystal with laminar overgrowth of aggregates of euhedral quartz; B) SEM image of euhedral quartz crystals growing over a partially re-dissolved gypsum; C) Genetic mechanism for the development of the euhedral quartz crystals within gypsum karst (after Forti, 1996, modified). and flowstones in the Pelagalli Cave (Forti \& Rossi, 1989). Its genesis is induced by $\mathrm{pH}$ lowering during complex biologically-driven reaction, which caused the deposition of alternating Fe-Mn, gypsum, and calcite deposits. For both chalcedony and opal the source of $\mathrm{SiO}_{2}$ is represented by the weathering of the clay minerals present in the thick interbedding of the gypsum strata.

Finally, millimeter-size euhedral crystal and skeletal aggregates of quartz were reported from Carlo Azzali Cave (Emilia Romagna, Italy), where they developed over corroded gypsum crystals (Forti, 1993) (Fig. 16 A, B). The quartz deposition must have occurred at a temperature lower than $40-50^{\circ} \mathrm{C}$, because gypsum was not at all transformed into anhydrite (the stable phasecalcium sulfate above this temperature).

The $\mathrm{SiO}_{2}$ comes from the weathering of an upper silica rich formation and the deposition of quartz instead of the more common opal was explained by Forti (1994) as being due to the anaerobic reduction of sulfates by slow seeping organic-rich water in saturated conditions (Fig. 16C). The oxidation of organic matter produces carbon dioxide that lowers $\mathrm{pH}$, thus inducing the deposition of silica as quartz euhedral crystals, while the reduction of sulfates to $\mathrm{H}_{2} \mathrm{~S}$ further decreases $\mathrm{pH}$ and simultaneously creates a solution that is undersaturated with respect to gypsum, which therefore is partially solubilized (Forti, 1994).

Sulfur is the only native element present in gypsum caves, where it has been found in two different occurrences. The first is Grave Grubbo Cave (Carrozzini et al., 1996), where sulfur is dispersed within a polymineral aggregate (along with $\mathrm{Al}$ and $\mathrm{Fe}$ oxides/hydroxides and opal). The second is in the
Befana Cave, as euhedral submillimetric crystals over gypsum coralloids and stalactites (Ronda Speleologica Imolese, 2011).

In both these occurrences sulfur comes from the oxidation of $\mathrm{H}_{2} \mathrm{~S}$ present in waters emerging just inside the caves. Its deposition was controlled by low $\mathrm{pH}$, which could not be buffered due to the absence of carbonates. In fact, it was proved that at very low $\mathrm{pH}$ the product of organic oxidation of the $\mathrm{S}^{2-}$ ions is $\mathrm{S}^{0}$ and not $\mathrm{SO}_{4}{ }^{2-}$ (Forti, 1985) (Fig. 17).

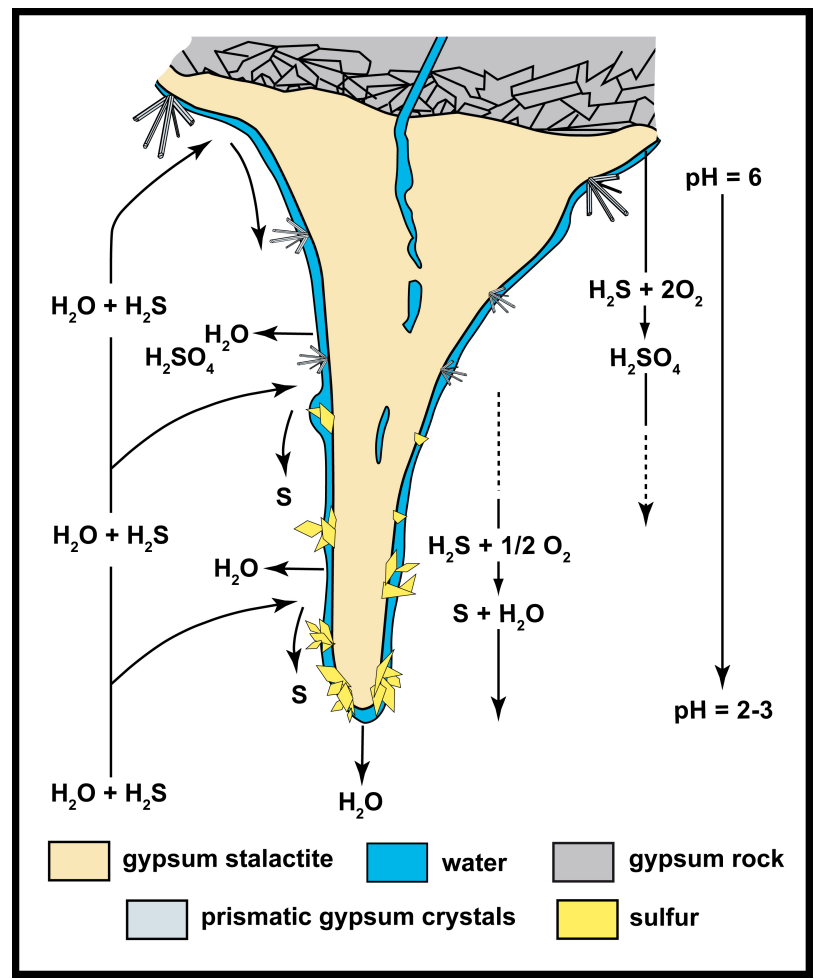

Fig. 17. Genetic mechanism for the development of sulfur crystals over gypsum speleothems. 
Finally, borate minerals are extremely rare in the cavern environment and one of the two known species has been observed in a gypsum cave. The borosilicate howlite, $\mathrm{Ca}_{2} \mathrm{~B}_{5} \mathrm{SiO}_{9}(\mathrm{OH})_{5}$ has been recently found within the flooded part of the Ordinskaya Cave (Potapov \& Parshina, 2010). It occurs in the drowned passages as 2 to $15 \mathrm{~cm}$ in diameter botryoidal aggregates hanging down from the roof to which they were connected by a small peduncle of residual gypsum. The central nucleus of the aggregate consists of extremely pure howlite whereas the $5 \mathrm{~mm}$ thick external shell is made of an admixture of calcite and rare chalcedony. This crust covers the whole aggregate except the point in contact with the gypsum roof. The howlite aggregates developed during the slow process of hydration of anhydrite induced by the vadose seepage of meteoric water. Later, the karst evolution within the gypsum exposed them inducing a recrystallization of this mineral and the rather simultaneous development of the surficial calcite and chalcedony crust. Because of this outer less soluble shell, howlite was not dissolved when the cave was completely flooded due to rising water of an artificial lake constructed nearby.

\section{FINAL REMARKS}

Albeit not exhaustive, the present outlook on the chemical deposits hosted by evaporite caves clearly evidences the importance of these cavities for the development of novel speleothems and several cave minerals, some of which unique to the evaporite environment. It is also clear that over the past 20 years only few new researches were performed within evaporite caves. Presently, the distribution of the investigated gypsum caves, covering most of the world's climatic areas, allows to state that the hosted speleothems are sufficiently well known, even if huge areas like those in Siberia and China are presently completely unexplored. Moreover some mineralogical classes (like oxides/hydroxides, and even more importantly, the phosphates) by sure need further investigations.

Although limited, the number of studied halite caves were sufficient enough to define, at least roughly, the complexity of the hosted halite speleothems, but they are surely too scarce to encompass all possible minerogenetic mechanisms acting in such caves all around the world. In particular, further research should be conducted in the large halite outcrops existing in China, which are still practically unknown.

We have even less knowledge of the situation with respect to anhydrite caves. Only the Upper Secchia Valley (Italy) evaporite karst may be considered sufficiently investigated from the point of view of chemical deposits. Instead, the information available on the Central Germany caves is limited and nothing is known from any other caves in anhydrite karst areas around the world.

It is therefore evident that in the future, amazing discoveries are waiting the cavers and scientists willing to investigate the relatively unknown world of chemical deposits in evaporite caves.

\section{ACKNOWLEDGMENTS}

The author thanks Stephan Kempe for the news and useful discussion on secondary deposits in anhydrite caves and Jo De Waele for the critical review of the manuscript. The author also thanks Bogdan P. Onac, Michal Filippi, and a third unknown reviewer for their suggestions that greatly improved this paper.

\section{REFERENCES}

Aldrovandi U., 1648 - Musaeum metallicum in libros 4 distributum Bartholomaeus Ambrosinus. Bononiae, Marcus Antonius Bernia, Ferronius, 979 p.

Alexandrowicz Z. (Ed.), 2000 - Crystal caves in the Wieliczka Salt Mine. Studia Naturae, 46: 1-205. (English summary)

Andrejchouk V.N. \& Klimchouk A.B., 2010 Geomocrobiology and redox geochemistry of the Karstified Miocene gypsum aquifer, Western Ukraine: the study from Zoloushka cave. Geomicrobiology Journal, 18 (3): 275-295. https://doi.org/10.1080/01490450152467796

Anonymous, 1988 - Die Barbarossahöhle im Kyffhausergebirge. Verwaltung der Barbarossahöhle, Kyffauser, 8 p.

Aldrovandi U., 1648 - Museum metallicum. Ferronius, Bologna: 979 p.

Badino G., Calaforra J.M., Forti P., Garofalo P. \& Sanna L., 2011 - The present day genesis and evolution of cave minerals inside the Ojo de la Reina cave (Naica Mine, Mexico). International Journal of Speleology, 40 (2): 125-131.

https://doi.org/10.5038/1827-806X.40.2.5

Bertolani M. \& Rossi A., 1972 - La Grotta Michele Gortani (31E) a Gessi di Zola Predosa (Bologna). Rassegna Speleologica Italiana, Memoria, 10: 206-246.

Bertolani M. \& Rossi A., 1986 - La petrografia del Tanone Grande della Gacciolina (154 E/Re) nelle evaporiti triassiche dell'alta val di Secchia. Le Grotte d'Italia, 4 (12): 79-105.

Bosák P., Bruthans J., Filippi M., Svoboda T. \& Šmíd J., 1999 - Karst and caves in salt diapirs, SE Zagros Mts., Islamic Republic of Iran. Acta Carsologica, 28 (2): 41-75.

Boschetti T., Cortecci G., Barbieri M. \& Mussi M., 2007 New and past geochemical data on fresh to brine waters of the Salar de Atacama and Andean Altiplano, northern Chile. Geofluids, 7 (1): 33-50. https://doi.org/10.1111/j.1468-8123.2006.00159.x

Calaforra J.M., 1998 - Karstologia de yesos. Universitad de Almeria, Monografias Ciencias Y tecnologia, 3: 388 p.

Calaforra J.M. \& Forti P., 1993 - Le palle di gesso e le stalagmiti cave: due nuove forme di concrezionamento gessoso scoperte nelle grotte di Sorbas (Andalusia, Spagna). XVI Congresso Nazionale di Speleologia, Udine 1990, 1: 73-88.

Calaforra J.M. \& Forti P., 1994 - Two new types of gypsum speleothems from New Mexico: gypsum trays and gypsum dust. National Speleological Society Bulletin, 56: 32-37.

Calaforra J.M. \& Forti P., 1999 - May the speleothems developing in gypsum karst be considered paleoclimatic indicators? INQUA Congress, Durban, South Africa, Book of Abstracts: 35-36.

Calaforra J.M., Forti P. \& Fernàndez-Cortès A., 2008 - The speleothems in gypsum caves and their paleoclimatological significance. Environmental Geology, 53 (5): 1099-1105. https://doi.org/10.1007/s00254-007-0737-3 
Calaforra J.M., Forti P. \& Pulido Bosch A., 1992 Nota preliminar sobre la influencia en la evolucion espeleogenetica de los yesos con special referencia a los afloramientos karsticos de Sorbas (Espana) y de EmiliaRomagna (Italia). Espeleotemas, 2: 9-18.

Calandri G. \& Ramella L., 1987 - Il sistema carsico di Darhedj (Algeria NE). Bollettino Gruppo Speleologico Imperiese CAI, 28: 2-10.

Cardona F. \& Vivier J., 2002 - Sota la sal de Cardona. Espeleo Club Garcia: 1-128.

Carrozzini B., De Paola M. \& Di Muccio L.A., 1996 - Primo contributo alla caratterizzazione mineralogica delle rocce affioranti in una cavità carsica dell'Alto Crotonese. Mineralogica Petrografica Acta, 38: 189-199.

Casali R. \& Forti P., 1969 - I cristalli di gesso del bolognese. Speleologia Emiliana, s.2, 1 (7): 25-48.

Cazzoli M., Forti P. \& Bettazzi L., 1988 - L'accrescimento di alabastri calcarei in grotte gessose: nuovi dati dalla Grotta dell'Acquafredda (3/ER/Bo) Sottoterra, 80: 16-23.

Chabert C. \& Courbon P., 1997 - Atlas des cavités non calcaire du Monde. Union Internationale de Speleologie, $110 \mathrm{p}$.

Cervellati R., Forti P. \& Ranuzzi F., 1975 - Epsomite: un minerale nuovo per le grotte bolognesi. Grotte d'Italia, 4 (5): 81-88

Chiesi M. \& Forti P., 1985 - Tre nuovi minerali per le grotte dell'Emilia-Romagna. Bollettino di Mineralogia e Paleontologia, 45: 14-18.

Chiesi M. \& Forti P., 1986 - Speleothems and secondary mineralisation of the "Inghiottitoio dei Tramonti", the largest cave in the Triassic evaporites of the EmiliaRomagna Region. Le Grotte d'Italia, 4 (12): 185-192.

Chiesi M. \& Forti P., 1988 - Fenomeni di concrezionamento e minerali secondari delle grotte del reggiano. In: Chiesi M. (Ed.), Guida alla speleologia nel Reggiano. Tecnograf, Reggio Emilia: 65-71.

Chiesi M. \& Forti P., 1992 - Le concrezionie le mineralizzazioni della Grotta della Milocchite MG2 (Milena, Caltanisetta). Mondo Sotterraneo, 16 (1-2): 19-28.

Chiesi M., Forti P., Panzica la Manna M. \& Scagliarini E., 1992 - Osservazioni preliminari sui fenomeni carisci nei gessi di Punta Alegre (Cuba). Speleologia, 27: 68-73.

Columbu A., De Waele J., Forti P., Montagna P., Picotti V., Pons-Branchu E., Hellstrom J., Bajo P. \& Drysdale R., 2015 - Gypsum caves as indicators of climate-driven river incision and aggradation in a rapidly uplifting region. Geology, 43 (6): 539-542. https://doi.org/10.1130/G36595.1

Dalmonte C. \& Forti P., 1995 - L'evoluzione delle concrezioni di carbonato di calcio all'interno delle grotte in gesso: dati sperimentali dal Parco dei Gessi Bolognesi. Sottoterra, 102: 32-40.

Dalmonte C., Forti P. \& Piancastelli S., 2003 - The evolution of carbonate speleothems in gypsum caves as indicators of microclimatic variations: new data from the Parco dei Gessi caves (Bologna, Italy). Memorie dell'Istituto Italiano di Speleologia, 2 (16): 65-82.

De Waele J. \& Padovan E., 2016 - The salt from within. NSS News, 74 (8): 4-9.

De Waele J., Forti P., Picotti V., Galli E., Rossi A., Brook G., Zini L. \& Cucchi F., 2009a - Cave deposits in Cordillera de la Sal (Atacama, Chile). In: Rossi P.L. (Editor), Geological constraints on the onset and evolution of an extreme environment: the Atacama Area, GeoActa, Special Publication, 2: 97-111.

De Waele J., Forti P., Picotti V. \& Zini L., 2009b - Halite macrocrystalline stalactites of the Atacama caves (Chile). In: White W.B. (Ed.), Proceedings $15^{\text {th }}$ International Congress of Speleology, Kerrville (Texas), 1: 296-299.
De Waele J., Carbone C., Sanna L., Vattano M., Galli E., Sauro F. \& Forti P., 2017 - Secondary minerals from salt caves in the Atacama Desert (Chile): a hyperarid and hypersaline environment with potential analogies to the Martian subsurface. International Journal of Speleology, 46 (1): 51-66. https://doi.org/10.5038/1827-806X.46.1.2063

Dzen-Litovsky A.I., 1940 - Le karst des gisements de sel de l'URSS. Izv Soc. Geogr. URSS, 72 (6): 764-773.

Ercolani M., Poletti K. \& Forti P., 2013 - Genesis and evolution of calcite bubbles in gypsum caves. In: Filippi M. \& Bosák P. (Eds.), Proceedings of the $16^{\text {th }}$ International Congress of Speleology, Brno 19-27 July 2013, 3: 443-448.

Fedorof E.S., 1883 - Kungurskije cave. Materialy po geologii Rossii, 11: 217-273 (in Russian).

Filippi M., Bruthans J., Palatinus L., Zare M. \& Asadi N., 2011 - Secondary halite deposits in the Iranian salt karst: general description and origin. International Journal of Speleology, 40 (2): 141-162. https://doi.org/10.5038/1827-806X.40.2.7

Ford D.C. \& Williams P., 2007 - Karst hydrogeololgy and geomorphology. Wiley, Chichester, $562 \mathrm{p}$. https://doi.org/10.1002/9781118684986

Forti P., 1983 - Brushite: un minerale nuovo delle grotte bolognesi Speleologia, 9: 41.

Forti P., 1985 - Le mineralizzazioni della grotta di Cala Fetente (Salerno, Campania). Mondo Sotterraneo, 9 (1-2): 43-50.

Forti P., 1986 - Speleothems and cave minerals of the gypsum karst of the Emilia Romagna Region, Italy. Atti "International Symposium on Evaporite Karst", Bologna: 259-266

Forti P., 1987 - Nuove concrezioni di grotta: le eccentriche di gesso di Santa Ninfa (Trapani). Notiziario di Mineralogia e Paleontologia, 52: 5-10.

Forti P., 1988 - Due nuovi meccanismi di formazione per i cristalli di gesso, osservati nella Grotta di Santa Ninfa (Trapani). Notiziario di Mineralogia e Paleontologia, 55: 5-12.

Forti P., 1993 - I quarzi dendritici sul gesso. Ipogea 19881993: $16-17$.

Forti P., 1994 - The role of sulfate-sulfite reactions in gypsum speleogenesis. Abstract of Papers "Breakthroughs in Karst Geomicrobiology and Redox Geochemistry, Colorado Springs: 21-22.

Forti P., 1996 - Speleothems and cave minerals in gypsum caves. International Journal of Speleology, 25 (3-4): 91-104. https://doi.org/10.5038/1827-806X.25.3.7

Forti P., 2003 - Un caso evidente di controllo climatico sugli speleotemi: il moonmilk del Salone Giordani e $i$ "cave raft" del Salone del Fango nella grotta della Spipola (Gessi Bolognesi). Atti $19^{\circ}$ Congresso Nazionale di Speleologia, Bologna: 115-126.

Forti P. \& Buzio A., 1985 - Le concrezionie le mineralizzazioni delle grotte del Monte Sinai. In Buzio A. (Ed.) Monte Sedom. Commissione Grandi Spedizioni della Società Speleologica Italiana, Pubbicazione 2: 23-39.

Forti P. \& Chiesi M., 1995 - A proposito di un particolare tipo di calcite flottante osservato nella Grotta Grave Grubbo - CB 258 (Verzino, Calabria). Atti e Memorie della Commissione Grotte Boegan, 32: 43-53.

Forti P. \& Lombardo N., 1998 - I depositi chimici del sistema carsico Grave Grubbo-Risorgente del Vallone Cufalo (Verzino, Calabria). Memorie dell'Istituto Italiano di Speleologia, 2 (10): 81-92.

Forti P. \& Lucci P., 2016 - Come si suiluppano i cristalli prismatici di gesso sulle stalattiti? Memoria Istituto Italiano di Speleologia, 2 (29): 113-118. 
Forti P. \& Marsigli M., 1978 - Sulla genesi delle infiorescenze gessose sopra le concrezioni alabastrine della Grotta Novella. Preprint XIII Congresso Nazionale di Speleologa, Perugia: 1-4.

Forti P. \& Querzè S., 1978 - I livelli neri delle concrezioni alabastrine della Grotta Novella. Preprint XIII Congresso Nazionale di Speleologa, Perugia: 1-5.

Forti P. \& Rabbi E., 1981 - The role of $\mathrm{CO}_{2}$ in gypsum speleogenesis: $I^{\circ}$ contribution International Journal of Speleology, 11: 207-218.

https://doi.org/10.5038/1827-806X.11.3.3

Forti P. \& Rossi A., 1987 - Le concrezioni poliminerali della Grotta di S. Ninfa: un esempio evidente dell'influenza degli equilibri solfuri-solfati sulla minerogenesi carsica. Atti e Memorie Commissione Grotte "E.Boegan", 26: 47-64.

Forti P. \& Rossi A., 1989 - Genesi ed evoluzione delle concrezioni di ossidi di ferro della grotta Pelagalli al Farneto (Bologna-Italia). Atti XV Congresso Nazionale di Speleologia, Castellana: 205-228.

Forti P., Barredo S., Costa G., Outes V. \& Re G., 1993 - Two peculiar karst forms of the gypsum outcrop between Zapala and Las Lajas (Neuquen, Argentina). Proceedings of the $11^{\text {th }}$ International Congress of Speleology, Beijing: 54-56.

Forti P., Buzio A. \& Frumkin A., 1984 - Le concrezioni di sale nelle grotte del Monte Sedom (Israele). Rivista Mineralogica Italiana, 2: 45-48.

Forti P., De Maria D. \& Rossi A., 2004 - The last mineralogical finding in the caves of the "Gessi Bolognesi" natural Park: the secondary dolomite. Memorie dell'Istituto Italiano di Speleologia, 2 (16): 87-94.

Frumkin A. \& Forti P., 1997 - Liquid Crystal Cave, Israel. In: Hill C.A. \& Forti P. (Eds.), Cave minerals of the world. Huntsville, National Speleological Society: 319-322.

Fryer S., 2005 - Halite caves of Atacama. National Speleological Society News, 63 (11): 4-19.

Giurgiu I., 1985 - Salt caves in the Vrancei's subcarpathians. Buletinul Clubului de Speologie "Emil Racoviță", Bucureşti, 9: 5-35 (in Romanian).

Hardie L.A., 1967 - The gypsum-anhydrite equilibrium at one atmosphere pressure. American Mineralogist, 52: 171-200.

Hill C.A., 1976 - Cave minerals. National Speleological Society, Huntsville, 138 p.

Hill C.A. \& Forti P., 1997 - Cave minerals of the world. National Speleological Society, Huntsville, Alabama, 464 p.

Kempe S., 2014 - How deep is hypogene? Gypsum caves in the South Harz. Karst Water Institute Special Publication, 18: 48-57.

Komensky A., 1966 - Potash and salt formations. Southwestern Caver, 5 (6): 85.

Korshunov V.V. \& Shavrina E.V., 1998 - Gypsum speleothems of freezing origin. Journal of Cave and Karst Studies, 60 (3): 146-150.

Kupetz M. \& Knolle F., 2015 - Die Mansfelder Schlotten Verbreitung und Genese der größsten mitteleuropäischen Anhydrit-Schichtgrenzhöhlen. Zeitschrift der Deutschen Gesellschaft für Geowissenschaften (German Journal of Geology), 166 (4): 327-339.

https://doi.org/10.1127/zdgg/2015/0037
Kupetz M. \& Mucke D., 1989 - Beitrage zur Geologie un Genese der Barbarossahohle bei Rottleben am Kyffhauser un Mansfelder Mulde. Wiss.-Techn. Inf. dienst. Aentr. Geol. Inst., Reihe A, 30 (2): 96-103.

Laghi T., 1806 - Di un nuovo sale fossile scoperto nel bolognese. Memorie Istituto Nazionale Italiano, 1 (1): 19-26.

Maksimovich G.A., 1969 - Caves of gypsum karst. Peshchery (Perm University), 7 (8): 5-29.

Malavolti F., 1949 - Morfologia carsica del Trias gessosocalcareo nell'Alta Valle del Secchia Memoria del Comitato Scientifico Centrale del Club Alpino Italiano, 1: 129-225.

Malkov V.N. \& Shavrina E.V., 1991 - Golubino caves on the Pinega River. Sotsyal'no-ekonomicheskie problem Evropeiskogo Sevara (in Russian).

Müller A., 1928 - Sur la découverte d'une Grotte à Cristeau dans les mines de Wieliczka. Situation de la Grotte. Zabytki Przyr. Nieożywionej Ziem Rzeczypos. Pol., 1: 24-29. (in Polish with French summary).

Peerman S. \& Belski D., 1991 - GYPKAP Another New Mexico Caving Project. National Speleological Society News, 49 (2): 57-63

Poluzzi A. \& Minguzzi V., 1998 - Un caso di biocostruzione in un ambiente di grotta. Memorie dell'Istituto Italiano di Speleologia, 2 (10): 93-100.

Ponta G., 1986 - The evaporite karst from Romania. Le Grotte d'Italia, 2 (12): 407-415.

Potapov S.S. \& Parshina N.V., 2010 - Howlite $\mathrm{Ca}_{2} \mathrm{~B}_{5} \mathrm{SiO}_{9}(\mathrm{OH})_{5}$ from Ordinskaya cave in Perm regionthe first find on the Ural. In: The problems of mineralogy, petrography and metallogeny, Scientific reading in memory Chirvinsky P.N. Collection of scientific papers Perm, 13: 83-91. (in Russian).

Ronda Speleologica Imolese, 2011 - Sistema carsico Grotta della Befana. In: Lucci P. \& Rossi A. (Eds.), Speleologia e geositi carsici in Emilia-Romagna. Pitagora, Bologna: 350-353.

Russo G.B., 1981 - Splitting of gypsum crystals. Zapiski Vsesoyuz. Mineral. Obsch., 110 (2): 167-171. (in Russian).

Santagata A., 1835 - Iter ad montem vulgo della Rocca. In: Bertoloni A. (Ed.), Commentarius de Mandragoris, Bologna: 371-392.

Turchinov I.I., 1993 - Secondary cave formation of the gypsum caves of Western Ukraine. Svet, 3 (9): 29-37 (in Russian).

Tchaikovskiy I., Kadebskaya O. \& Kalinina T., 2015 Mineral pellicles on the lakes surface of warm and cold zones in Kungur Ice Cave. Acta Carsologica, 44 (1): 101-106. https://doi.org/10.3986/ac.v44i1.609

Volkov S.N., Andreychouk V.N. \& Janchouk E., 1986 Birnessite stalactite from Zoloushka cave (Bukovina, Ukraine) (in Russian). Peshchery, 20: 113-114.

Volkov S.N., Andreychouk V.N., Janchouk E. \& Smirnov B.I., 1987 - Modern ferro-manganese deposits from the Zoloushka cave. Academia Nauk SSSR, 292 (2): 451454. (in Russian).

White W.B., 1962 - Introduction to the symposium on cave mineralogy. NSS Bulletin, 24: 55-56.

Yuhua G. \& Lin Hua S., 1986 - Salt karst in Quinghai plateau, China. Le Grotte d'Italia, 4 (12): 337-345. 